\title{
Bond Spreads and Economic Activity in Eight European Economies 1
}

\begin{abstract}
We provide new insights into the relationship between financial market tightness and real activity using a new database of corporate bonds issued in eight European countries. Bond spreads have a significant negative relationship with four real activity variables at horizons 1-8 quarters ahead. The relationship is robust to adding measures of monetary policy tightness and leading indicators, providing strong support for models previously only evaluated on US data. A sub-set of northern European countries have similar sensitivity of real GDP to bond spreads, but others have greater sensitivity to bond spreads, revealing diverse responses in Europe to financial market tightness.
\end{abstract}

The global financial crisis that began in 2007 and the ensuing recession have spurred renewed interest in the relationship between tightness of financial markets and the business cycle. A number of studies have considered the effects of financial conditions on the real economy (Hatzius et al. 2010, Cardarelli et al. 2011, and others summarised in Kliesen et al. 2012). New models that develop the financial accelerator idea of Gertler and Gilchrist (1994) and Bernanke et al. (1999) incorporate "risk shocks" emanating from the financial sector that are then transmitted to real output (e.g. Gertler and Karadi, 2009; Jermann and Quadrini, 2012). A negative risk shock means that borrowers can finance less investment for a given net worth. Attention has focused on corporate bond markets, which have increased in significance since the financial crisis because of the reduced availability of bank finance (Kaya and Meyer, 2013; Kaya and Wang, 2014). The yield spread between corporate bonds and lowest-risk government bonds reflects investors' willingness to lend to companies and incorporates two time-varying components: the default risk itself, and systematic risk associated with the fact that expected default loss is correlated with equity price movements (Elton et al. 2001). ${ }^{2}$

Even before the crisis (Gertler and Lown, 1999; Mody and Taylor, 2004; and King et al., 2007) had shown that high yield bond spreads have predictive power for output fluctuations in the United States. The most recent research on the relationship between bond yields and real activity has been conducted by Gilchrist et al. (2009a), Gilchrist and Zakrajšek (2012) and Faust et al. (2013) on US bond market data. They confirm that changes in bond spreads offer early warnings of a decline in real activity, so that they are powerful indicators of approaching

\footnotetext{
${ }^{1}$ We thank the ESRC for funding under grant number ES/H003053/1. We benefitted greatly from comments of the editor, Morten Ravn, and three anonymous referees as well as seminar participants at the Bank of England; the Money, Macro and Finance conference, Dublin, Sept 2012; and Yonsei University, Seoul. We thank Robert Anderton, Gabe de Bondt, John Duca, John Gathergood, Simon Gilchrist, Christoph Görtz, Michael Joyce, Peter Karadi, Kevin Lee, Phil Molyneux, Simon Price, Peter Sinclair, Oreste Tristani, Philip Vermeulen, Mark Watson, Mike Wickens, Vladimir Yankov and Egon Zakrajšek for additional comments. Any remaining errors are our own. Corresponding Author: Paul Mizen, Professor of Monetary Economics, University of Nottingham, University Park, Nottingham, NG7 2RD, United Kingdom; Email: paul.mizen@nottingham.ac.uk.

${ }^{2}$ As Elton et al. (2001), p. 267) put it, "[i]f corporate bond returns move systematically with other assets in the market whereas government bonds do not, then corporate bond expected returns would require a risk premium to compensate for the non-diversifiability of corporate bond risk, just like any other asset."
} 
recessions. Rather than use an off-the-shelf index, these latest contributions employ a bottomup approach that concentrates on the careful selection of bonds to create a bond spread index that is not distorted by embedded options or illiquidity. While these papers provide convincing evidence that bond spreads predict future changes in real activity in the United States, there is no corresponding analysis for the euro area and the United Kingdom, the second and third largest bond markets respectively, mainly because these bond markets are comparatively young, but also because of a lack of country-specific bond indices. ${ }^{3}$ We construct corporate bond indices for eight European countries, using the approach pioneered by Gilchrist et al. (2009a). This provides the first measures of corporate bond market tightness specific to each country, which can be used to explore hypotheses previously only tested on US data.

Our paper makes several contributions to the literature with potentially important policy implications for European economies. The first main contribution is to show that bond spreads have significant predictive ability over macroeconomic variables for the largest European economies, providing a signal of incipient economic downturns in these countries. We evaluate the importance of the bond spread versus measures of domestic monetary policy tightness and leading indicators, as well as spillover effects from regionally or globally important economies such as the United States and Germany, and find that bond spreads offer a substantial contribution to the prediction of real activity.

Our second main contribution exploits the cross-sectional dimension of our data to compare the responses to the bond spread measures in different countries across Europe. There is a high degree of consistency in the statistical significance of the bond spread measures at different horizons for each country, with a commonly signed negative coefficient in a regression explaining real GDP growth. But the scale of the response is not equal, reflecting heterogeneity in the sensitivity of different European countries to financial conditions, measured by corporate bond spreads. These may reflect the differences in the depth of capital markets among the countries in the sample. When we test for equality of the bond spread coefficients across all European countries (including the UK), we reject the null, and for euro area countries alone we also reject the null of equality. But for a subset of euro area countries with the largest corporate bond markets (Germany, France and Netherlands), we cannot reject the null that the coefficients on bond spreads are equal. In addition to the fact that bond spreads differ in magnitude across Europe, the sensitivity of the response of real GDP to these spreads is also greater for Austria, Belgium, Italy and Spain than it is for France, Germany and the Netherlands. A financial shock may raise spreads by larger amounts in some peripheral economies of Europe; our paper shows that the impact on real GDP in those economies is also greater due to higher sensitivity of activity to spreads. This implies that the impact of bond spreads on real activity measures differs across countries in Europe, despite a common monetary policy stance, and considerable real economic ties between countries.

In addition to these contributions, we also decompose the spread by removing the influence of default risk and bond characteristics before testing the information content in the

\footnotetext{
${ }^{3}$ European bond markets had $\$ 1933.3$ bn of outstanding corporate bonds in December 2013, of which $\$ 1229.2 \mathrm{bn}$ were issued in euro and $\$ 704.1 \mathrm{bn}$ in sterling. They are the second and third largest bond markets, respectively, after the United States, according to data from the Bank for International Settlements.
} 
residual bond spreads (the "excess bond premium"). ${ }^{4}$ This confirms the predictive ability of the spread even after purging it of these potentially distorting factors. We find that bond spreads in the euro area are correlated with the tightness of credit supply as reported in ECB surveys of bank lending, and we show that a worsening of bank credit supply has a significant negative correlation with future real GDP growth, whereas a survey measure of credit demand does not. ${ }^{5}$ Our interpretation of these results is that tightness of credit supply from banks and bond markets occurs at the same time and has a similar degree of predictive ability over real activity. Finally, in an online appendix, we show that our model has superior out-of-sample forecast performance in forecasting real GDP growth relative to that of a model that omits bond spreads, and other basic alternatives such as a random walk model and an autoregressive model. Our findings are evaluated using our unique new panel of data from October 2001-May 2011 for Austria, Belgium, France, Germany, Italy, Netherlands, and Spain and from July 1994-May 2011 for the United Kingdom. ${ }^{6}$ This index is the first of its kind for Europe, where there are no benchmark indices for bond spreads over a comparable sample period, and data on European bonds has not been systematically constructed into a bond spread index.

The paper is organised as follows. Section 1 discusses the recent literature. We then explain recent developments in European corporate bond markets and differences between countries, and the nature of our data in Section 2. In Section 3 we explain our methodology. Section 4 then provides results of the predictive ability of bond spreads on real economic activity and tests various hypotheses about cross country differences, out of sample forecast performance and the relationship to bank lending surveys. Section 5 concludes.

\section{A Brief Review of the Literature}

In an early contribution Davis and Fagan (1997) tested for the predictive content of the bond quality spread (defined as the difference between private and government bond yields) for three European countries (Denmark, Germany and the UK). They found a significant relationship for bond spreads only in Germany for inflation and output growth, but their out-of-sample forecasting results were weak. De Bondt (2004) offered the first empirical examination of the balance sheet channel in the euro area since the introduction of the single currency. He approximated the external finance premium using the monthly average of daily observations of the spread between long-term BBB-rated euro area corporate bond yields and the 7- to 10-year government bond yield over a short sample (January 1999 to June 2001). His results suggested that corporate bond spreads predict the growth of real GDP and of industrial production.

\footnotetext{
${ }^{4}$ The decomposition stems from the "credit spread puzzle" in corporate finance, which shows less than half of all variation in corporate bond credit spreads can be explained by bond characteristics and financial indicators of the issuer (see Elton et al., 2001), leaving a substantial unexplained portion due to other factors, as discussed by Gilchrist and Zakrajsek (2012) p 1693.

${ }^{5}$ De Bondt and Hahn (2010) show that an Area-wide Leading Indicator (ALI) of monthly business conditions can give accurate predictions of real GDP movements up to two years ahead, De Bondt et al. (2010) also offer evidence that bank lending surveys can predict real activity two year ahead.

${ }^{6}$ Prior to October 2001 Bloomberg does not record corporate bonds that meet our selection criteria.
} 
Recent papers by Mueller (2009) and Buchmann (2011) use euro-area data on economic activity and corporate debt. Mueller (2009) finds that spreads across maturities and rating classes are informative of future growth. He uses quarterly US data for CPI and real GDP growth between 1992Q2 and 2006Q1 to test the information content of zero-coupon corporate bond yields (AAA to B) for the whole term structure (three months to ten years). He finds that a seemingly arbitrary combination of credit spreads results in the highest $\mathrm{R}^{2}$, suggesting that the whole term structure of credit spreads across rating classes contains relevant information. He also decomposes the bond spread using principal component analysis and concludes that one of the three latent factors (which is independent of the macro variables), termed 'the credit factor', captures virtually all predictive power in corporate bond spreads. The credit factor is highly correlated with the Federal Reserve's Index of Tighter Loan Standards. Buchmann (2011) studies the Merrill Lynch corporate bond index for investment grade bonds including both financial and non-financial corporations of various credit qualities and terms to maturity. To calculate the spread, he uses the averaged relevant benchmark government bond yield series for maturities ranging from 1 up to 10,15, 20, and 30 years. He evaluates a variety of alternative models using the Least Angle Regression procedure for model selection, and finds that corporate bond spreads consistently help to predict real activity in the euro area.

All of these papers make useful contributions to the literature, but none of them uses the bottom-up construction method based on individual bond-level data pioneered by Gilchrist, Yankov and Zakrajšek (2009), Gilchrist and Zakrajšek (2012) and Faust et al. (2013). This method has the advantage that it removes prepayment and liquidity risks (Duca, 1999), and also removes callable bonds that could distort the yields. Papers that use averaged data on bond yields suffer from distortions because they do not remove these risks. Gilchrist, Yankov and Zakrajšek (2009) construct their bond spread index from monthly data on prices of senior unsecured corporate debt traded in the secondary market over the 1990-2008 period, issued by about 900 U.S. nonfinancial corporations. They construct portfolio-based bond spreads (according to the issuer's expected probability of default, and use Moody's KMV expected default frequency measure) which are shown to contain substantial predictive power for economic activity over either a 12-month or 4-quarter horizon (the frequency of the data is both monthly and quarterly). They also construct portfolios of stock returns, which serve as controls for news about firms' future earnings, and examine the information content of bond spreads that is orthogonal to the information contained in stock prices of the same set of firms. They conclude that most of the predictive power of spreads comes from the middle of the bond-quality spectrum, a result also documented by Mueller (2009). The unexpected component of bond spreads is shown to explain $30 \%$ of the variance in economic activity at two- to four-year horizons. Faust et al. (2013) adopt a similar method but they include bonds issued by financial firms as well as non-financial firms in their sample. A notable contribution in this paper is the use of the first principal component from a database of 15 macroeconomic indicators and 110 financial indicators with bond spreads to predict real activity. They select from a range of models using a Bayesian model averaging method to show that in the preferred models bond spreads explain a large amount of variation in real activity measures. 


\section{Characteristics of Bond Markets and Data}

In this section we document the key features of European bond markets and the country-level differences in these markets. We then consider our data sources, construction methods and the data characteristics.

\subsection{European Corporate Bond Markets}

The major European bond markets are segmented into a euro-denominated and a sterlingdenominated market, which are respectively the second and third largest corporate bond markets in the world. We consider eight different European countries that issue bonds in these markets (Austria, Belgium, France, Germany, Italy, Netherlands, Spain and the UK). Seven of these countries have the same euro benchmark rate, while the UK market has the sterling benchmark. The euro corporate bond market received a remarkable boost from the introduction of the euro in 1999 as the volume of all types of bonds issued more than doubled from $\$ 273 \mathrm{bn}$ to $\$ 657$ bn according to Rajan and Zingales (2003). The volume outstanding of private nonfinancial sector bonds issued in euros was about \$1.1tn in December 2013.

Bank lending dominates the debt financing market in Europe, and comprises about 75\% of all corporate debt outstanding in euros (Kaya and Wang, 2014) and about 66\% of debt finance in sterling (Pattani and Wackett, 2011). This points to high bank dependency in these countries, but in recent years there has been a shift towards bond finance. Issuance of corporate bonds was high by the standards of recent years in 2009, 2010 and 2012, and many firms have refinanced existing debt using bonds instead of bank loans. In the euro area the growth rate of bond issuance has exceeded the pre-crisis average in all years except 2011, while bank lending growth has been negative. These same trends are apparent in the United Kingdom, where bank lending growth to non-financial companies has been negative since 2009, contributing to lower loan volumes, and although net external finance raised has fallen each year since 2009, the proportion that has been financed with corporate bonds has increased.

Figure 1 shows that spreads on financial and non-financial corporate bonds have risen and become more volatile in Europe since 2007, but the relative cost of bond finance for nonfinancial corporations relative to bank finance has declined. Across all segments of the market it has been lower than the refinancing cost from banks since mid-2010. This has made bond finance more attractive for firms that can access the markets, promoting a change in capital structure over time. Yields are low enough for corporate issuance to be relatively cheap while at the same time they are sufficiently high for investors compared with the alternatives such as sovereign bonds, whose yields have been depressed by the actions of central banks through quantitative easing (Gagnon et al. 2011 and Joyce et al. 2011, Joyce and Tong, 2012).

The picture at the country level varies in several dimensions that influence transmission of financial shocks through various channels. Figure 2 reports the issuance patterns in total and by country since 2000 in constant euros. It shows that issuance of corporate bonds in the euro markets peaked in 2009 and has again risen to similar levels in 2013, which reflects the strong bond issuance in the largest corporate bond markets France, Germany and the Netherlands in 2009 and 2013. Italy has also been a contributor to the high issuance volumes in 2013. 
In Germany the gross issuance of corporate bonds by the non-financial sector was high in times that bank lending was limited; for example, in 2002-2004 issuance increased each year reaching a peak in 2004 at €28.6bn, but from this point it fell every year until 2007, when it dropped to $€ 6.1 \mathrm{bn}$. In 2008 issuance again began to rise, and reached a peak of $€ 36.6 \mathrm{bn}$ in 2009 and has maintained a high level of issuance in the years following 2009 that is comparable to the previous high level in 2002-2004. A common pattern of this type is seen in other European countries, suggesting bond issuance rises when bank lending is constrained (a result confirmed by Kaya and Wang, 2014). In France, Italy, the Netherlands and the United Kingdom gross corporate bond issuance peaked in 2009 , but fell back in subsequent years, only to peak again in 2012 and 2013. This pattern was repeated in countries with smaller bond markets.

The total volume of bonds outstanding in euros issued by the non-financial corporate sector was $€ 887 \mathrm{bn}$ at the end of 2013. The largest contribution in the euro area was by companies resident in France at $€ 373 \mathrm{bn}$, followed by Germany at $€ 118 \mathrm{bn}$, Italy at $€ 117 \mathrm{bn}$ and the Netherlands at $€ 56.9 \mathrm{bn}$ at end of 2013. Since December 1998 the volumes outstanding in Italy have increased six-fold, while in Germany they have increased by three times, and in France by two and a half times. The volumes outstanding in France have grown by $€ 100$ bn since early 2007. The size of the United Kingdom bond market is slightly larger than the bond market in France, and it is therefore the largest corporate bond market for an individual country in Europe. Figure 3a plots the volumes outstanding in constant euros at the end of 2007 and 2013 for the euro area countries. Figure $3 \mathrm{~b}$ plots the volumes outstanding as a percentage to GDP and France dominates the scene with Austria.

\subsection{Data}

We employ the bottom-up approach of Gilchrist et al. (2009a) and Gilchrist and Zakrajšek (2012) to construct a country-level bond spread index for eight European countries. Our selection criteria remove bonds with embedded options and bonds that are illiquid; we ignore bonds with excessively short maturities (less than 1 year) or very long maturities, and we use bonds with fixed coupons with a minimum amount outstanding of $€ 1 \mathrm{mn}$.

Our dataset consists of 500 non-financial corporate bonds from October 2001-May 2011 for Austria, Belgium, France, Germany, Italy, Netherlands, and Spain and from July 1994-May 2011 for the United Kingdom. ${ }^{7}$ The countries were chosen to represent the largest economies in the euro area, plus the United Kingdom, which between them have the two largest bond markets - in terms of volume and importance - outside the United States. The choice of the time span for the euro area was imposed by data availability after the introduction of the euro.

We used Bloomberg L.P. to extract market data at bond and firm level and other macroeconomic data were obtained from the IMF, the World Bank, Eurostat and the OECD international databases. Additionally, we used Moody's KMV database of Expected Default Frequencies (EDFs) at firm level to obtain a bond risk measure for the bond issuers in our

\footnotetext{
${ }^{7}$ Our sample periods vary in our results section depending on availability of other data described in this section. When performing the decomposition of the original bond spread our initial sample is reduced due to the availability of the expected default frequency measure.
} 
sample. ${ }^{8}$ Monthly data on EDFs were obtained from Moody's from January 1992 until August 2010; we use Moody's unique firm personal identification (PID) code reporting the company name and ticker to manually match the bond issuers in our sample with the Moody's PID to assign the EDF data. 81\% (407 bonds) of our bonds had a PID code, but due to the different coverage of sampling periods between the two datasets, the final matched dataset consisted of 269 bonds ( 92 companies) across 176 time periods from February 2003 until August 2010 for the seven euro area countries, and from January 1996 until August 2010 for the UK.

Using the universe of domestic corporate bonds with Bloomberg coverage, we select corporate bonds in Europe according to the same criteria as the most recent literature comprising only corporate non-financial bonds issued in Austria, Belgium, France, Germany, Italy, Netherlands, Spain and the UK, denominated in local currency, with a fixed coupon schedule (no index-linked or step-ups), that are outstanding senior unsecured bonds i.e. they have not yet matured and are not subordinate to other bonds - yielding a matched sample of bonds for 190 companies across 45 industry sectors. ${ }^{9}$ We measure the yield to maturity, the fixed coupon rate, and the full schedule of coupon payments at each pricing date for each bond issue. We exclude callable bonds, and we ensure that all observations are in the range between 1.5 basis points and 2,800 basis points to mitigate potential problems with outliers. ${ }^{10}$ This leaves us with 500 bonds to construct the bond spread as the difference between the actual yield to maturity of the bond and its corresponding theoretical risk-free yield, which is calculated in two steps. We first obtain the price as the sum of the present value of the bond's cash-flows discounted using the continuously-compounded zero-coupon euro and sterling benchmark rates. These are linearly interpolated such that the maturity of a given cash-flow payment exactly matches the maturity of the spot rate that is used to discount that cash flow. We then use this price to calculate the risk-free rate applicable to that bond. ${ }^{11}$

\footnotetext{
${ }^{8}$ Moody's KMV provides the Expected Default Frequency measure-a forward-looking probability of default metric - which is available for quoted firms and sovereigns and is the market standard bond risk measure. The EDF measure is compiled using Moody's default database and leverages market data, industry, volatility, financial statement data, and historical default information in a proprietary financial model.

${ }^{9}$ The distribution of industries across countries shows some diversity, but there are also common elements, for example the most prominent industries in the countries in our sample are Electrical, Oil and Gas, Telecoms and Chemical Industries.

${ }^{10}$ Less than nine percent of European bonds are callable bonds, in contrast to the sample used by Gilchrist and Zakrajšek (2012) for the United States, where two-thirds of bonds were callable.

11 The rich bond-level aspect of our Bloomberg dataset allows us to construct a risk-free bond yield for every bond in the sample at every pricing date. This theoretical bond mimics exactly the coupon payment schedule and maturity of the underlying corporate bond (therefore the spread measure will not be biased by mismatched maturities or coupon schedules between the two bonds being compared). So, the price calculation involves using zero-coupon government rates which have been interpolated by Bloomberg to match exactly the term of each coupon payment. These zero-coupon government rates are the euro and GBP Bloomberg Benchmark curves for euro- and GBP-denominated bonds, respectively. The EURO Benchmark curve consists of French government bonds at short maturities (up to one year) and German government bonds only (at longer maturities). The GBP Bloomberg Benchmark curve consists of UK government bonds at all maturities. So in this sense, the eurodenominated corporate bonds in our sample are essentially compared against a theoretical bond whose coupon payments are discounted by the German government interpolated bond rates of identical maturity. When we recalculated the spreads using German Bunds as the benchmark in place of the theoretical risk free rates
} 
The bond spread is then defined as $S_{i t k}=y_{i t k}-y_{i t k}^{f}$, where $y_{i t k}$ is the yield of bond $k$ issued in country $i$ in month $t$, and $y_{i t k}^{f}$ is its corresponding risk-free yield. The bond spread index at the country-level for each country, $i$, and time period $t$ is then calculated as the arithmetic (or cross-sectional) average across all bond spreads, $k$, in a given country: $S_{i t}=\frac{1}{N_{i t}} \sum_{k=1}^{K_{i t}} S_{i t k}$, where $N_{i t}$ is the aggregate number of bond observations in country $i$ at month or quarter $t$. In our regressions we make use of eight separate country-specific bond spreads based on this measure, but in order to illustrate our measure graphically we can aggregate further (across countries, $i$ ) in order to present a single bond spread index, $S_{t}=\sum_{i=1}^{8} S_{i t}$.

Figure 4 shows the bond spreads for individual countries. The correlation between the series is remarkably high; the UK, the Netherlands, Spain and France all peak in 2008Q4 and other countries peak one quarter later. Austria is an outlier in the sense that its peak is much higher than the rest and conditions did not moderate as quickly as in other countries. This may be a country-specific effect, since the Moody's KMV expected default frequency measure of default risk was also particularly high for Austria compared to other countries.

In our regressions we include the term spread and the real interest rate. These variables were used by Harvey (1988), Estrella and Hardouvelis (1991), Estrella and Mishkin (1998) and Hamilton and Kim (2002) to explain real activity. We also use the OECD's country-specific composite leading indicator variable as an additional explanatory variable. ${ }^{12}$ The term spread is defined as the difference between the 10-year generic government bond yield and the 3-month generic government bond, and the real interest rate is defined as the difference between the official nominal interest rate (published by the ECB and the Bank of England, respectively) and the inflation rate obtained from IMF's IFS database. The generic government bond yields are the country-specific benchmark bond yields of constant maturity available from Bloomberg.

We also have other bond-specific data such as Macaulay duration, amount outstanding, amount issued, whether the bond has any embedded options, the issue and maturity dates, Standard \& Poor's bond rating, market of issue, currency, issuer name, and the issuer's industry sector. This information is used to predict the bond spread, and to extract the excess bond premium.

In Europe, the commercial paper market has only recently grown in size and only financial institutions access this market (there are no non-financial corporate commercial paper issuers in Europe, according to Bloomberg). Similarly, due to the smaller bond market in individual European countries, data availability for Baa or Aaa spreads is extremely limited over our sample. For this reason, there is limited value from utilising the CP-Bill spread and the BaaAaa spreads in our studies.

\subsection{Descriptive Statistics}

\footnotetext{
described here, the results were qualitatively similar, and the correlations between the two spreads were 0.76 on average across countries and as high as 0.98 for some individual countries.

12 The series used in our analysis is the amplitude-adjusted monthly series transformed into a four-quarter difference, where the actual original series in levels is centred on 100.
} 
Table $1 \mathrm{a}$ reports data for bond characteristics in aggregate across all the countries in our sample and Table $1 \mathrm{~b}$ reports the breakdown by country. There are 19,574 bond-firm observations in our European data sample. The mean firm in our sample has between 4 and 5 senior unsecured issues outstanding in any given month, with the majority of the firms having less than 10 issues trading in the secondary market at any point in time.

Table 1a shows that the bonds have an average nominal yield of $4.87 \%$ and an average risk free yield of $3.16 \%$. The average coupon rate in the sample is $5.36 \%$ with a maximum of $8.88 \%$. On average a bond has an expected return of 170.72 basis points above the comparable risk-free artificial bond and a standard deviation of 152.5 basis points, which reflects the wide range of the bond quality in our sample. ${ }^{13}$ The bond spread index in Europe has a mean of 140.3 basis points above the risk-free rate.

In terms of default risk as measured by the S\&P bond ratings, our sample spans almost the entire spectrum of bond quality from financially vulnerable firms rated B- to secure firms rated AA. The distribution of the amount of debt outstanding of these issues is positively skewed, with the range running from $€ 7.7$ million to $€ 3.2$ billion. The maturity of the issues in our sample is long, with an average maturity at issue of 12.6 years and an average remaining term-tomaturity of 9.7 years. The average duration is equal to approximately 7 years; this is less than the average maturity since all bonds in our sample pay regular non-zero coupon payments over their life.

Table $1 \mathrm{~b}$ presents the additional country-level variables (from the monthly sample) used to explain real activity. It is immediately obvious that a higher total number of corporate bonds have been issued in France and the United Kingdom than any other European country, while firms in Germany, Italy and the Netherlands have issued a similar number in total over our sample. France stands out as the country with the highest average number of bonds per firm followed by the Netherlands, Italy and Spain, the UK, and then Germany, Belgium and Austria. The bond spreads also differ, with Austria having the largest spread over the calculated risk-free rate. The average maturity of bonds at issue is about 20 years in the UK, and between 10-12 years for most European countries except Austria, Belgium and Germany.

\section{Methodological Issues}

\subsection{The Baseline Regression Model}

To assess the predictive ability of bond spreads we use a specification in which the contemporaneous value of the bond spread is an explanatory variable for the change in real economic activity over the following $h$ periods. The initial specification is:

$\Delta^{h} Y_{i t+h}=\alpha_{1}+\beta_{1} * S_{i t}+\sum_{k=1}^{K} \varphi_{1 k} * \Delta Y_{i t-k}+u_{1 i}+e_{1 i t+h}$

where $Y$ is either real GDP, employment, the aggregate fixed capital investment or the industrial production index, and $\Delta^{h} Y_{i t+h}$ is the $h$-period growth rate of the economic activity indicator from

13 The equivalent Bloomberg Z-Spread index has a mean and standard deviation of approximately 142 bps. 
time $t$ to time $t+h .{ }^{14}$ Subscript $h$ denotes the $h$-period ahead change in variable $Y$ (i.e., $h=3,12$, and 24 months for monthly data; and $h=1,4$, and 8 quarters for quarterly data) and $i=1, \ldots, 8$ denotes the country index. Equation (1) has a dynamic structure similar to Faust et al. (2013), including lagged first-differenced terms in variable $Y$, where the maximum lag, $\mathrm{K}$, is determined by the Akaike Information Criterion (AIC). It includes the country-specific bond spread, $S_{i t}$, the importance of which is the main focus of our paper. $S_{i t}$ denotes the bond spread index constructed as the difference between the actual yield to maturity of the bond issue and its corresponding risk-free rate, $S_{i t}=y_{i t}-y_{i t}^{f}$. Finally, $u_{1 i}$ represents the country-specific intercept (fixed effect) allowing for unobserved heterogeneity. $e_{1 i t+h}$ is the idiosyncratic error, where $u_{1 i}+e_{1 i t+h}$ is the composite error. Estimation issues related to Equation (1) are discussed below.

To control for monetary policy tightening we include the influence of the term spread and the real short-term interest rate, and to anticipate changes in future real activity we include the composite leading indicators. The model is then given by:

$\Delta^{h} Y_{i t+h}=\alpha_{2}+\beta_{2} * S_{i t}+\sum_{k=1}^{K} \varphi_{2 k} * \Delta Y_{i t-k}+\gamma_{2} * X_{i t}+u_{2 i}+e_{2 i t+h}$

where $X_{i t}$ is the vector of controls.

Equations (1) and (2) imply that the response of $\Delta^{h} Y_{i t+h}$ to the bond spread is identical across countries. To examine the hypothesis that coefficients may differ when estimated individually for each country, we re-specify equation (2) to relax the parameter homogeneity assumption:

$\Delta^{h} Y_{i t+h}=\alpha_{3 i}+\beta_{3 i} * S_{i t}+\sum_{k=1}^{K} \varphi_{3 k i} * \Delta Y_{i t-k}+\gamma_{3 i} * X_{i t}+u_{3 i}+e_{3 i t+h}$

We address the issues concerning the estimators used for equations (1) - (3) below. A key element in our paper is that the hypothesis of equality of the $\beta_{3 i}$ is rejected by the data, which implies that there are significant differences in the response of $\Delta^{h} Y_{i t+h}$ to bond spreads over the eight European countries.

\subsection{The EBP and the Decomposition}

The bond spread may be distorted by bond-specific factors. As a robustness test we use the method of Gilchrist and Zakrajšek (2012) to control for these factors by regressing the spread for each bond on the bond's characteristics, and constructing an adjusted spread, termed the excess bond premium by Gilchrist and Zakrajšek (2012), from the residuals of this regression. To explain the predictable part of $\ln \left(1+S_{i t k}\right)$ we use the firm-specific expected default, $\ln \left(1+E D F_{i t k}\right)$, and a vector of bond-specific characteristics, $Z_{i t k}$, where $k$ denotes the bond, and $i$ denotes the country. ${ }^{15}$ These bond-specific characteristics correspond to those used by King

\footnotetext{
14 The log growth rate of $\mathrm{Y}$ in country i between period $t$ and $\mathrm{t}+\mathrm{h}$ is defined as: $\Delta \Delta^{\mathrm{h}} \mathrm{Y}_{\mathrm{it}+\mathrm{h}}=\frac{\mathrm{c}}{\mathrm{h}+1} \ln \left(\frac{\mathrm{Y}_{\mathrm{it}+\mathrm{h}}}{\mathrm{Y}_{\mathrm{it}-1}}\right)$. $\mathrm{c}$ is a scaling constant that depends on the frequency of the data (e.g., c $=1200$ for monthly data, and c $=400$ for quarterly data). 15 Natural logarithms of one plus the measures of the spread and the EDF provide useful transformations to control for heteroskedasticity, given that the distribution of the two variables is highly skewed. They also avoid negative values inherent in calculations with small values. In this case, the percentage change interpretations are
} 
and Khang (2005), who allow for liquidity and tax premiums, mid-Macaulay duration, $D U R_{i t k}$, the amount outstanding, $A O S_{i k}$, the fixed coupon rate, $C P N_{i k}$, and the age of the bond issue, $A G E_{i t k}$. What cannot be predicted using these variables (i.e. the residual from the regression) is defined as the unpredictable part of the bond spread. Figure 5 reports the Moody's KMV expected default frequency by country, and it is clear that the default risk in each country rises to a peak after the Lehman event in 2008Q4. There is a marked increase in the expected frequency of default after the financial crisis compared to the pre-crisis period 2004-2007.

We estimate specifications that allow for a linear relationship between EDF and the spread (4a) as well as a quadratic version (4b).

$\ln \left(1+S_{i t k}\right)=a_{4}+\beta_{4} * \ln \left(1+E D F_{i t k}\right)+\gamma_{4} * \ln \left(Z_{i t k}\right)+\varepsilon_{4 i t k}$

$\ln \left(1+S_{i t k}\right)=a_{5}+\beta_{5} * \ln \left(1+E D F_{i t k}\right)+\delta_{5} * \ln \left(1+E D F_{i t k}\right)^{2}+\gamma_{5} * \ln \left(Z_{i t k}\right)+\varepsilon_{5 i t k}$

The relationships are estimated using OLS at bond level at monthly frequency, with two-way clustering of standard errors at both country (i) and time (t) dimensions (Cameron et al., 2011). The resulting standard errors are thus robust to arbitrary within-panel autocorrelation (clustering on country) and to arbitrary contemporaneous cross-panel correlation (clustering on time). The regressions also include industry and bond rating fixed effects. In this way we obtain the (antilog) point prediction for the bond spread for bond $k$ in country $i$ at time $t$.

Having obtained our measure of the predicted spread as the fitted values from the specification above, we can now define the excess bond premium as the difference between the actual bond spread of bond $k$ issued in country $i$ at time $t$, and the predicted spread of the same bond at time $t$ as $E B P_{i t k}=S_{i t k}-\widehat{S}_{i t k}$. This linear decomposition takes place at the bond level such that both the predicted spread and the EBP are bond-specific. We then take the crosssectional average across bonds in country $i$ at time $t$, and construct a country-level index for the EBP and the predicted spread as follows:

$\hat{S}_{i t}=\frac{1}{N_{i t}} \sum_{k=1}^{K i t} \hat{S}_{i t k}$

and

$E B P_{i t}=\frac{1}{N_{i t}} \sum_{k=1}^{K_{i t}} E B P_{i t k}$.

We estimate the following equation using the dynamic fixed effects estimator:

$\Delta^{h} Y_{i t+h}=\alpha_{7}+\beta_{7 i} * E B P_{i t}+\sum_{k=1}^{K} \varphi_{7 k} * \Delta Y_{i t-k}+\delta_{7} \hat{S}_{i t}+\gamma_{7} * X_{i t}+u_{7 i}+e_{7 i t+h}$

Potentially this equation could suffer from Nickell bias (Nickell, 1981) in the estimates, but the large $T$ in our case will ensure that any bias will be small.

\subsection{Estimation Issues}

closely preserved and it is acceptable to interpret the estimates as if we used the logarithm of the variable (Wooldridge, 2006, chapter 6.2, page 185). 
The models discussed above are estimated using methods appropriate for panel datasets with a relatively long time dimension. Our basic approach uses dynamic fixed effects (DFE) estimation that constrains coefficients to be equal across countries as implied by equation (2). As a check on this constraint, we also apply mean group estimation (MGE), as proposed by Pesaran and Smith (1995), which permits hypothesis testing on the cross-country mean whilst estimating the model separately by OLS for each country (thus requiring sufficient $\mathrm{T}$ in each case). The DFE results are reported in the upper panels of Tables 2-5 and the MGE estimates are reported in the lower panels. The MGE sections of the tables report averages of the individual coefficients estimated for each country. The underlying assumption behind the MGE model is that all coefficients vary randomly across countries around a constant value following a random coefficient model; this is assumed for convenience, and mean group estimation would be equally valid if coefficients had fixed estimates that differed across countries.

Baltagi, Griffin and Xiong (2000) document that DFE models may suffer from simultaneous equation bias due to the correlation of the error term with the lagged dependent variable. With a large $T$, as in our case, the bias should be small. Since the MGE results do not suffer from this bias (the equations for each country are estimated independently) we can test for bias in our DFE coefficients by using a Hausman test to determine whether there is a significant difference between the DFE and MGE estimates.

Estimators with fixed effects allow intercepts to vary across the $N$ dimension, but typically restrict the slope parameters to be homogeneous. This can be inappropriate for econometric as well as economic reasons (Pesaran and Smith, 1995). Tables 6 and 7 will provide estimates of equation (3) where we relax the homogeneity assumption on all parameters for bond spreads and for the excess bond premium respectively. The coefficient estimates are obtained from a dynamic fixed effects model in which we have an interaction term between the bond spread (or the excess bond premium) and the country dummy. We do not report a mean group estimate, which by its design offers an estimate of the average effect across groups.

The construction of the dependent variable as the growth rate over the next $h$ periods of an economic activity indicator introduces serial correlation in the error terms within a country, when $h$ is greater than one. This will cause least squares to yield inconsistent estimates of the standard errors and thus lead to invalid inference. To take into account this overlapping structure we use Driscoll-Kraay (1998) standard errors that are Newey-West-type standard errors to allow for autocorrelated errors across countries.

\subsection{Summary and Hypotheses}

We estimate equations (2), (3) and (7) for real GDP growth one, four and eight quarters into the future with the following control variables: the real interest rate, the term spread and the fourquarter change in the OECD composite leading indicator for the relevant country. The real interest rate represents the real cost of capital, and a higher rate is expected to be associated with lower output growth. If the term spread reflects expectations of future short-term interest rates, according to the expectations hypothesis, then assuming interest rates are higher when output is high, this hypothesis suggests that the term spread should have a positive coefficient. The composite leading indicator is defined so that a higher value predicts higher output, so it 
should have a positive coefficient. We also present some results with growth in employment, fixed capital formation and industrial production rather than real GDP growth. Monthly data are used for industrial production, and quarterly data for all the other cases.

Our first hypothesis (H1) is that higher bond spreads are associated with lower future real activity growth, because they indicate a higher cost of borrowing relative to the risk-free rate. The test is a $t$-test of the statistical significance of the coefficient of the bond spread variable in equation (2). Our second hypothesis (H2) is that the bond spread coefficient differs across the eight countries in our sample, allowing us to determine whether there is a homogeneous or heterogeneous response to indicators of financial stress arising from the bond market. The test is an F-test of equality of the coefficients on the interaction term between the country dummy and the bond spread variable in equation (3). In an online appendix we evaluate the out-ofsample forecast performance of equation (3) against alternatives such as a random walk model, an autoregressive model and a model similar to equation (3) that excludes the bond spreads, by comparing the mean squared forecast error (MSFE) of each model. Finally, we decompose the spread and evaluate whether the differences found between the bond spreads for each country remain when we account for bond characteristics and default risk. The test involves an F-test of equality of the coefficients of the interaction term between the country dummy and the excess bond premium (EBP) in equation (7). We report the results of our hypotheses in Section 5.

\section{Results}

\subsection{The Predictive Ability of Bond Spreads for Real Activity}

This section addresses Hypothesis 1, that bond spreads predict growth in future real activity. Table 2 reports the result of estimating equation (2) for growth in real GDP, employment, capital investment and industrial production at the 4-quarter horizon. The top panel of Table 2 shows the results for equation (2) estimated using the dynamic fixed effects model in which the number of lags of the first difference in $Y$ is determined by the Akaike Information Criterion (AIC). In the bottom panel equation (2) is re-estimated using the Pesaran \& Smith (1995) mean group estimator because of potential bias in the DFE estimates.

We find that growth in real GDP, employment, investment and industrial production all fall as the bond spread rises. In six cases the coefficient is significantly negative at the $1 \%$ level, in the seventh case at the $5 \%$ level and in the eighth case at the $10 \%$ level. Thus bond spreads measured at the end of quarter $t$ predict changes in real activity measured over quarters $t$ to $t+4$. The estimated impact effect of a 100 basis point increase in the bond spread ranges from a fall of $0.5 \%$ in employment to a $3.3 \%$ reduction in investment and $3.6 \%$ fall in industrial production; real GDP falls by $1.3 \%$ (based on the dynamic fixed effects estimates). The negative impact of the bond spread is statistically significant for all cases at the four-quarter horizon irrespective of whether each model is estimated by DFE or MGE, and the magnitude of the estimated parameters for each real activity indicator is similar across the two estimation methods. The mean group estimates are slightly larger in absolute size (except for employment), but the Hausman test reported at the foot of the table does not reject the null of equality for any of the estimated coefficients on bond spreads provided by DFE and MGE estimators. This confirms that we cannot reject the null hypothesis that the estimated coefficients on bond spreads are 
unbiased in the DFE model, and it leaves little doubt that they help predict growth in the different measures of real activity in Europe one year ahead.

The real interest rate, which measures the tightness of monetary policy, has the expected signs and is significant when estimated using the mean group estimator, but the coefficients are insignificantly different from zero when estimated by DFE. ${ }^{16}$ The country CLI has a positive and significant coefficient in equation (2). In preliminary versions of the model (available in an online appendix) we add two other forward-looking measures based on consumer confidence and economic sentiment, but the country CLI measure was the most consistently significant. The financial accelerator model predicts that bond spreads should still have significant predictive ability for future real activity even when other predictors of future activity are included in the model, and by including the country CLI we show this is the case. Only the term spread has an unexpected negative sign, which we would not expect in normal times. This may occur because recent monetary policy easing has generated a low and occasionally negative term spread in Europe, while at least some European economies have experienced a recovery in real activity, and thus it may appear that the term spread has a negative impact on real activity if this episode dominates. ${ }^{17}$ These conditions may be responsible for the negatively signed coefficients on the term spread.

In the remaining tables we use real GDP growth as the dependent variable since Table 2 shows the alternatives produce similar results. Table 3 assesses the performance of the bond spread as a predictor of output growth over different forecast horizons (one, four and eight quarters). We report results from equation (2) estimated by DFE in the first panel of the Table, and by MGE in the second panel. The results for one and eight quarters are consistent with our findings in Table 2 at the four-quarter horizon: the coefficient on the bond spread is highly significant at all three horizons with the expected negative sign. The magnitude is very similar at all three horizons: a 1\% increase in bond spreads predicts real GDP growth will fall by $1.3 \%$ one quarter ahead, $1.3 \%$ four quarters ahead and 1.1\% eight quarters ahead based on the DFE estimator, while the results from MGE are very similar. The Hausman test reported at the foot of the table does not reject the null that the estimates of the bond spread coefficients for real GDP growth provided by DFE and MGE estimators are equal, which implies that there is no significant bias in the DFE estimates.

The term spread and the real interest rate mostly have the expected negative signs but are insignificant when estimated by DFE. The country CLI variable should anticipate output fluctuations to some degree, and it proves to have a positive coefficient that is significant at a one-quarter or four-quarter horizon. We are able to uphold the prediction of models that embed a financial accelerator or models with a financial shock due to tightening of credit availability.

\footnotetext{
${ }^{16}$ By contrast, over much longer samples, Adrian and Estrella (2008) find that the term spread in particular is able to correctly predict slowdowns following a monetary tightening in the United States.

${ }^{17}$ We note the important point raised by Estrella (2005) that the precise relationship depends on the policy reaction function of the monetary authorities, and when there is a response to both inflation and output the relationship between yield spread and output may weaken.
} 
Both types of model imply that bond spreads will have independent predictive power over future output.

In the context of the literature on information asymmetry, we can interpret movements in the bond spread to reflect either the change in the firm's net worth, as in financial accelerator models (Gertler and Gilchrist, 1994; Bernanke et al., 1999; de Bondt, 2004; and Gilchrist et al., $2009 \mathrm{~b}$ ), or variation in the availability of credit from financial intermediaries (cf. Gertler and Karadi, 2009; Jermann and Quadrini, 2012) and through bond markets (cf. Adrian et al. 2010; Gertler and Kiyotaki 2010; He and Krishnamurthy, 2010; Gertler and Karadi 2011; and Brunnermeier and Sanikov, 2014). Recent work by Jermann and Quadrini (2012) argues that the financial sector can provide a separate source of shocks that influences the business cycle, beyond acting as a propagating mechanism for shocks that occur in other sectors of the economy. These channels operate even after accounting for other plausible explanations for changes in real activity.

The widening of bond spreads may therefore reflect idiosyncratic shocks to the net worth of firms, which de Bondt (2004) calls 'balance sheet' effects, discussed in a structural DSGE context by Gilchrist et al. (2009b) and Christiano et al. (2010), or shocks that emanate from banks, affecting the availability of credit, as explained by Jermann and Quadrini (2012). The significance of the bond spread as a predictor of output growth demonstrates the importance of these theoretical channels. Hubrich and Tetlow (2012) argue that there are 'myriad ways in which financial stress manifests itself - widened spreads of risky bonds over Treasury bond rates, jumps in volatility, substantial increases in liquidity premiums in bond markets, shifts in the equity premium - together with the multiplicity of channels through which stress can operate'. We find that a bond spread can provide an early indication of incipient economic downturns in real activity even when macro-financial linkages are complex and changing over time (as documented by Prieto et al. 2013).

Rather than constructing an index, an alternative way of capturing the common element in bond spreads is to use principal components analysis. In Table 4 we report the results after extracting the first principal component of the bond spreads for our eight European countries. The first principal component is the common element to all bond spreads derived from a country-specific factor model. The percentage of variation in real activity predicted by this factor shows the extent to which the many different bonds issued by firms in the eight European economies can anticipate the growth in real GDP in each country. The results do not look remarkably different from the constructed bond spread index for each country that we used in Table 3. Figure 6 shows that the first principal component picks up a large part of the variation in bond spreads. The correlation between the first principal factor and our bond spread is 0.67 . However, while signs and significance of the coefficients are similar, the goodness of fit in Table 4 is lower than in Table 3, suggesting that the common component in the bond spreads explains less than the individual country indices, and considerably less at the eight-quarter horizon.

Finally, to be sure that the results are not corrupted by omitted variables of interest, in Table 5 we add to the regression shown in Table 3 two United States variables to capture international spillovers: the country CLI and growth in industrial production. Both of these 
variables are expected to have positive coefficients. ${ }^{18}$ The coefficient of the US CLI, where significant, is unexpectedly negative, but US industrial production has a significant positive coefficient in the top panel (DFE), although not in the bottom panel (MGE). The results in the top panel of Table 5, estimated using DFE, show that the country CLI has a positive and significant coefficient in the estimated equation for real GDP growth in Europe at one- and four-quarter horizons, while the US composite leading indicator is at best mildly significant at the fourquarter horizon but gains greater significance at eight quarters ahead. Growth in US industrial production, on the other hand, has a significant positive coefficient in the equation for real GDP growth up to two years ahead. Even allowing for these additional influences, we find that the bond spread remains negative and significant at all horizons as in previous tables. The results in the lower panel of Table 5 obtained using the MGE are similar, with stronger negative coefficients on the bond spread and weaker influence of the separate consolidated leading indicators and industrial production measures.

None of the models above allows the coefficient on the bond spread to differ from country to country. It is quite likely that response to bond spreads will differ between countries, so we allow the estimated slope coefficient to differ by country in the next section.

\subsection{Allowing for Variation in the Response to Bond Spreads Across Europe}

In this section we test Hypothesis 2, that the bond spread coefficient varies across countries. Table 6 shows the results of estimating the DFE model with separate coefficients for each country from an interaction between bond spreads and the country dummies. The difference between the results reported in Table 6 and Table 3 is that in Table 6 we estimate the slope coefficient for the bond spread on a country-by-country basis, while in Table 3 we estimated a common coefficient.

The estimated bond spread coefficients in Table 6 have a negative sign for all countries, and at the one-quarter and four-quarter horizons the coefficients are significantly different from zero. Only at the eight-quarter horizon do we find two cases where the coefficient is correctly signed but insignificant. Other variables have similar signs and significance to the model reported in Table 3. When we conduct a test of equality of coefficients across all eight European countries using an F-test, we reject the null at the $1 \%$ level. Although the coefficient tends to be particularly high for the United Kingdom, this does not just reflect differences between the UK and the Eurozone, for we also reject the null at the $1 \%$ level if we test for equality of coefficients across the Eurozone countries. Finally if we test equality across a subset of northern Eurozone countries with the largest bond markets - France, Germany and the Netherlands - we cannot reject the null of equality for short- or medium-term horizons. When we consider that the euro zone sample includes countries as diverse from a financial perspective as Spain and Germany, this is not so surprising. But when we examine the constituent countries in the euro area, we find that it is a sub-set of the northern countries (Germany, France and Netherlands) that have experienced a common response to bond spreads.

${ }^{18}$ Adding German leading indicators in place of country-specific indicators made little difference to the results. 
These results have potentially important implications. Not only do the magnitudes of bond spreads differ across Europe, but the sensitivity of the predictions of real GDP growth from bond spreads between the countries of Europe also differs. The response is greater in Austria, Belgium, Italy and Spain than it is in France, Germany and the Netherlands.

\subsection{Prediction with the Excess Bond Premium}

We now explore the decomposition of the bond spread into the predicted spread and the excess bond premium. Table 7 reports ordinary least squares regressions of the bond spread on the expected default measure and other bond characteristics such as the coupon, the duration of the bond (in years), the amount outstanding, and the age of the bond (also in years) in order to estimate the predicted spread. We also include two-way fixed effects for industry and bond ratings to measure the issuing firm's financial health. The predicted spread therefore captures bond-specific features that may distort the general spread measure. The excess bond premium is constructed as the difference between the actual and the predicted spread from this regression model. We evaluate linear and non-linear specifications in columns 1 and 2 of Table 7; the first includes the variables mentioned above as regressors, and the second adds the square of the expected default measure to allow for a quadratic relationship between the spread and expected default. Because we have excluded the callable bonds from our sample, we do not need to evaluate the impact of the level, slope and curvature of the term structure on the bond spreads, making our models simpler to estimate.

We find that the default measure has a significant positive influence on the spread (column 1), indicating that investors require to be compensated for the probability of default, but the square of this term is also significant (column 2), and this has a negative sign, suggesting a convex relationship between the spread and the default probability. Other variables are significant but less important in both specifications: the coupon has a positive and significant coefficient (possibly reflecting tax effects), while the age of the bond has a small positive effect, although duration and amount outstanding do not appear to be significant determinants of the spread. The fixed effects for industry and ratings are significant, and we can reject the hypothesis that the coefficients on these variables are jointly equal to zero. ${ }^{19}$

Figures 7 and 8 refer to the quadratic version of the model (column 2). The cross-country aggregated actual and predicted values are provided in Figure 7 and the excess bond premium is given in Figure 8. Figure 7 shows that the predicted spread tends to co-move positively with the actual spread, but the peak occurs later than the peak in the actual bond spread. This may be due to the heavy influence of the default risk in the prediction equation, and defaults tend to follow after the point of maximum intensity of financial stress. As a result of this difference in timing, Figure 8 shows there is a peak in the excess bond premium that occurs at about the same

\footnotetext{
${ }^{19}$ We experimented with another specification, where we interact the linear term in the expected default measure with country dummies to allow the slope coefficient on the EDF and the intercept to be country specific; this would imply the expected default frequency influences the bond spread in these European countries with different magnitudes, reflecting any institutional differences between countries. This model showed a marginal improvement in the goodness-of-fit statistic but there were counterintuitive signs on the coefficient for the Netherlands, suggesting a decrease in the bond spread would result from an increase in the expected default measure.
} 
time as the peak in the bond spread, which points to non-systematic components in the bond spread that determine peaks in the bond spread.

Table 8 evaluates the prediction of the real GDP growth rate using the decomposition of bond spreads in a dynamic fixed effects regression at one-, four- or eight-quarter horizons. As in Table 6 we include the term spread, the real interest rate and the OECD composite leading indicator, and allow the slope coefficient to differ by country. Our findings show that the term spread and the real interest rate variables are not significant in our regressions at horizons of one-, four- or eight-quarters, with only one exception. The predicted part of the bond spread also is insignificant at all horizons, but the EBP has a consistently negative and significant sign (except for Austria) that shows evidence that the predictive performance of real GDP growth can be explained by the spread required by investors beyond the compensation for expected defaults. 20 This finding matches the reported findings of Gilchrist and Zakrajšek (2012) for the United States, since they also found the excess bond premium to have greater predictive power than the default-risk element of the bond spreads. In US data the predicted spread had no forecasting power from the mid-1980s onwards, but the EBP was a robust predictor of real GDP growth.

These results corroborate our findings for bond spreads, and we interpret the excess bond premia in the same way as we did the bond spreads. The results offer support for the financial accelerator models of Gertler and Gilchrist (1994) and Bernanke et al. (1999), where the financial system amplifies the effects of financial shocks, and also supports Jermann and Quadrini (2012), where financial shocks have an independent impact on firms' ability to borrow and ultimately to invest or produce output. Since we have controlled for default risk and bond characteristics, we can be more certain that the widening of excess bond premia reflect changes in investors' risk preferences.

If bond spreads reflect the financial sector's willingness to lend, then they should be correlated with the availability of credit from banks as suggested by several theoretical models (cf. Adrian et al. 2010; Gertler and Kiyotaki 2010; He and Krishnamurthy, 2010; Gertler and Karadi 2011; and Brunnermeier and Sanikov, 2014). Figure 9 plots the European Central Bank measure of tightness in bank lending standards (from 2003 onwards) against our excess bond premium for the euro area. It shows in the most recent crisis that that there is a positive relationship between bond spreads and tightness of bank lending standards. We provide evidence in the online appendix that the spread and the tightness of bank lending standards have a positive relationship after controlling for many other variables that measure the monetary policy stance and expectations of future economic conditions. Therefore, even for countries where the firms are more heavily bank-dependent, such as Germany, bond spreads offer a signal of tightening in credit conditions more broadly.

To determine whether the premium implied by the bond market is correlated with tight bank lending conditions, we refer to the Bank Lending Survey (BLS), which has been reported

\footnotetext{
${ }^{20}$ In results that are not reported here, we find that if the composite leading indicator is dropped from our regressions explaining real GDP growth at different horizons, the predicted spread regains its significance. The correlation between the predicted spread and country CLI is approximately -0.09 . This may indicate the result is not entirely robust, and we therefore put less emphasis on the model with bond spread decompositions than on our earlier results.
} 
for the euro area as a whole by the European Central Bank every quarter since 2003Q1. The survey provides an independent source of information on credit supply and credit demand that provides identification of the source of the decline in real activity. In our analysis we replace the EBP variable in our real GDP growth equation with the tightness of credit supply measure from the BLS. Table 9 reports the results which corroborate the earlier findings of de Bondt et al. (2010) who find supply standards are a good predictor of real GDP growth in the Euro area.

In the first panel we report the results when we introduce the credit supply tightness measure from the BLS into a regression predicting real GDP growth at the one-, four- or eightquarter horizon. We cannot use individual country survey data because the ECB only reports information on credit surveys for selected countries at the euro area level, but the results show that the tightness of the bank lending supply for the euro area as a whole from the BLS has a negative and significant coefficient in a model where it replaces the EBP. In case the objection is raised that these findings do not allow for changes in the demand for credit, we control for these effects using information from the BLS on demand for credit (as others do, notably de Bondt et al. 2010, Bassett et al. 2013 and Kaya and Wang, 2014). Our results show a significant negative coefficient on the credit supply measure, while the coefficient estimates on the credit demand measure are insignificant. Our interpretation of these results is that - for the market as a whole - tightness of credit supply from banks and bond markets does appear to occur at the same time and has a similar degree of predictive ability over real activity. These findings show that tightening of bank lending standards and widening bond spreads are both good indicators of a decline in future real activity. The results in this sub-section help us to identify that these signals are related to availability of credit supply (not demand) as a predictor of contraction in real activity and they corroborate findings by others (cf. Bassett et al. 2013 and Becker and Ivashina, 2014 for the United States, and de Bondt et al., 2010, Ciccarelli et al., 2010 and Kaya and Wang, 2014, for Europe).

\section{Conclusions}

In this paper we examine the relationship between financial market tightness and real activity in Europe. We evaluate the importance of bond spreads, and of excess bond premiums extracted by removing the predictable part of the spread, in predicting real activity at the individual country level in-sample and out-of-sample. By comparison with other measures of monetary policy tightness and signals from leading indicators of economic performance, we find that the bond spreads and excess bond premiums consistently predict changes in real activity. These findings are consistent at different forecast horizons and are robust to different measures of the bond spreads. When we compare the predictive ability of the bond spread and the excess bond premium in individual countries, we find that only a subset of northern European countries has similar coefficients on the bond spreads. Other countries in the euro area have different coefficients, as does the UK.

Our results imply that the careful selection of the European bonds used to construct the bond spread index, excluding those with embedded options and illiquid secondary markets, delivers a robust indicator of financial market tightness that is distinct from tightness due to monetary policy measures or leading indicators of economic activity in Europe, confirming 
earlier results by Gilchrist et al. (2009a), Gilchrist and Zakrajšek (2012) and Faust et al. (2013) using data for the United States. The interpretation of the bond spreads is consistent with the 'bank lending' and 'balance sheet' channels previously supported by de Bondt (2004) and de Bondt et al. (2010), and has similar predictive ability to tightening bank lending standards. Our results show that a credit supply measure from the ECB Bank Lending Survey has a significant negative coefficient in an equation to predict real GDP growth, while credit demand does not. Our interpretation of these results is that tightness of credit supply from banks and bond markets occurs at the same time and has a similar degree of predictive ability over real activity. This appears to support a separate financial markets channel identified by Jermann and Quadrini (2012) that influences the business cycle, beyond acting as a propagating mechanism for shocks that occur in other sectors of the economy.

Michael Bleaney (University of Nottingham), Paul Mizen (University of Nottingham) and Veronica Veleanu (University of Surrey)

\section{References}

Adrian, T. and A. Estrella (2008). 'Monetary tightening cycles and the predictability of economic activity', Economics Letters, vol. 99(2), pp. 260-264.

Adrian, T., E. Moench, and H. S. Shin (2010). 'Financial intermediation, asset prices, and macroeconomic dynamics', Federal Reserve Bank of New York Staff Report.

Alexander, G.J., A.K. Edwards and M.G. Ferri (2000). 'The determinants of trading volume of high-yields corporate bonds', Journal of Financial Markets, vol. 3, pp. 177-204.

Baltagi, B. H., J.M.Griffin, and W. Xiong. (2000). 'To pool or not to pool? Homogeneous versus heterogeneous estimators applied to cigarette demand', Review of Economics and Statistics, vol. 82, pp. 117-126

Bassett, W.F., M.B Chosak, , J.C. Driscoll and E. Zakrajšek (2013). 'Changes in bank lending standards and the macroeconomy', Finance and Economics Discussion Series No 2012-24, Federal Reserve Board, Washington, D.C

Becker, B. and V. Ivashina (2014). 'Cyclicality of credit supply: Firm level evidence', Journal of Monetary Economics, vol. 62, pp. 76-93.

Bernanke, B. S., M. Gertler, and S. Gilchrist (1999). 'The financial accelerator in a quantitative business cycle framework', in (J. B. Taylor and M. Woodford eds.) The Handbook of Macroeconomics, pp. 1341-1393, Amsterdam: Elsevier Science B.V.

Brunnermeier, M. K., and Y. Sannikov (2014). 'A macroeconomic model with a financial sector', American Economic Review, vol. 104(3), pp. 379-42.

Buchmann, M. (2011). 'Corporate bond spreads and real activity in the euro area - least angle regression forecasting and the probability of the recession', European Central Bank Working Paper No 1286.

Cameron, A. C., J. B. Gelbach, and D. L. Miller (2011). 'Robust inference with multi-way clustering', Journal of Business and Economic Statistics, vol. 29, pp. 238-249.

Cardarelli, R. Elekdag, S. and L. Subir (2011). 'Financial stress and economic contractions', Journal of Financial Stability, vol. 7, pp. 78-97.

Ciccarelli, M., A. Maddeloni and J-L Peydro (2010). 'Trusting bankers: A new look at the credit channel of monetary policy', Working Paper No 1228, European Central Bank.

Davis, E.P. and G. Fagan (1997). 'Are financial spreads useful indicators for future inflation and output growth in EU countries?', Journal of Applied Econometrics, vol. 12(6), pp. 701-714.

De Bondt, G. (2004). 'The balance sheet channel of monetary policy: First empirical evidence for the euro area corporate bond market', International Journal of Finance and Economics, vol. 9, pp. 219-228.

De Bondt, G. and E. Hahn (2010). 'Predicting recessions and recoveries in real time: The euro area-wide leading indicator (ALI)', Working Paper No 1246, European Central Bank.

De Bondt, G., A. Maddeloni, J-L. Peydro and S. Scopel (2010). 'The euro area bank lending survey matters: Empirical evidence for credit and output growth', Working Paper No 1160, European Central Bank. 
Driscoll J. C. and A. C. Kraay (1998). 'Consistent covariance matrix estimation with spatially dependent panel data', Review of Economics and Statistics, vol. 80(4), pp. 549-560.

Duca, J.V. (1999). 'An overview of what bond market indicators tell us', Economic and Financial Review, Federal Reserve Bank of Dallas.

Estrella, A. and G. A. Hardouvelis (1991). 'The term structure as predictor of real economic activity',Journal of Finance, vol. 46, pp. 555-576.

Estrella, A. and F. S. Mishkin (1998). 'Predicting U.S. recessions: Financial variables as leading indicators', Review of Economics and Statistics, vol. 80, pp. 45-61.

Estrella, A. (2005). 'Why does the yield curve predict output and inflation?', Economic Journal, vol. 115 (505), pp. 722-744.

Faust, J., S. Gilchrist, J. H. Wright, and E. Zakrajšek (2013). 'Bond spreads as predictors of real-time economic activity: A Bayesian model-averaging approach', Review of Economics and Statistics vol. 95(5), pp. 15011519.

Gagnon, J., Raskin, M., Remache, J. and Sack, B. (2011). 'Large-scale asset purchases by the Federal Reserve: Did they work?', FRBNY Economic Policy Review, May 2011.

Gertler, M. and C. S. Lown (1999). 'The Information in the high-yield bond spread for the business cycle: Evidence and some implications', Oxford Review of Economic Policy, vol. 15, pp. 132-150.

Gertler, M. and S. Gilchrist (1994). 'Monetary policy, business cycles, and the behavior of small manufacturing firms', Quarterly Journal of Economics, vol. 109, pp. 309-40.

Gertler, M., and P. Karadi (2011). 'A model of unconventional monetary policy', Journal of Monetary Economics, vol. 58(1), pp. 17-34.

Gertler, M., and N. Kiyotaki (2010). 'Financial intermediation and credit policy in business cycle analysis', in (B. M. Friedman, and M. Woodford eds.) Handbook of Macroeconomics, pp. 547-599. North-Holland, Elsevier, Amsterdam.

Gilchrist, S., V. Yankov, and E. Zakrajšek (2009). 'Bond market shocks and economic fluctuations: Evidence from corporate bond and stock markets', Journal of Monetary Economics, vol. 56, pp. 471-493.

Gilchrist, S. and E. Zakrajšek (2012). 'Credit spreads and business cycle fluctuations', American Economic Review, vol. 102(4), pp. 1692-1720.

Hamilton, J. D. and D. H. Kim (2002). 'A re-examination of the predictability of economic activity using the yield spread', Journal of Money, Credit, and Banking, vol. 34, pp.340-360.

Harvey, C. R. (1988). 'The real term structure and consumption growth', Journal of Financial Economics, vol. 22, pp. 305-322.

Hatzius, J., P. Hooper, F. Mishkin, K.L. Schoenholtz, and M.W. Watson (2010). 'Financial conditions indexes: A fresh look after the financial crisis', Working Paper Series No. 16150, National Bureau of Economic Research

He, Z. and A. Krishnamurthy (2010). 'Intermediary asset pricing', mimeo, Kellog School of Management, Northwestern University.

Hubrich, K. and R. J. Tetlow (2012) "Financial stress and economic dynamics: the transmission of crises" Finance and Economics Discussion Series paper no. 2012-82, Federal Reserve Board, Washington, D.C

Jermann, U. and V. Quadrini (2012). 'Macroeconomic effects of financial shocks', American Economic Review, vol. 102(1), pp. 238-71.

Joyce, M., Lasaosa, A., Stevens, I. and Tong, M. (2011). 'The financial market impact of quantitative easing', International Journal of Central Banking, vol. 7(3), pp. 113-161.

Joyce, M., and M. Tong (2012). 'QE and the gilt market: a disaggregated analysis', Economic Journal, vol. 122, pp. F348-384.

Kaya, O. and T. Meyer (2013). 'Corporate bond issuance in Europe: where do we stand and where are we heading?', Research Paper, Deutsche Bank.

Kaya, O. and L. Wang (2014). 'The role of bank lending tightening on corporate bond issuance in the eurozone', Working Paper No. 456, Centre for Financial Studies, Frankfurt.

King, T. D. and K. Khang (2005). 'On the importance of systematic risk factors in explaining the cross-section of corporate bond yield spreads', Journal of Banking and Finance, vol. 29, pp. 3141-3158.

Kliesen, K., M.T. Owyang and E.K. Vermann (2012). 'Disentangling diverse measures: A survey of financial stress indexes', Federal Reserve Bank of St. Louis Review vol. 94, pp. 369-398, September/October 2012.

Löffler, G., (2007). 'The complementary nature of ratings and market-based measures of default risk', Journal of Fixed Income, vol. 17(1), pp. 38-47.

Mody, A. and M.P. Taylor (2004). 'Financial predictors of real activity and financial accelerator', Economics Letters, vol. 82(2), pp. 167-172.

Mueller, P. (2009). 'Credit spreads and real activity', EFA 2008 Athens Meetings Paper. Available at SSRN: http://ssrn.com/abstract=1105728 
Pattani, A., and J. Wackett (2011). 'Going public: UK companies' use of capital markets', Bank of England Quarterly Bulletin, vol. 51(4), pp. 319-330.

Pesaran, M. H. and R.P. Smith, (1995). 'Estimating long-run relationships from dynamic heterogeneous panels', Journal of Econometrics, vol. 68(1), pp. 79-113.

Philippon, T. (2009). 'The bond market's Q', Quarterly Journal of Economics vol. 124, pp 1011-1056.

Prieto, E., Eickmeier, S. and M. Marcellino (2013). 'Time variation in macro-financial linkages', Discussion Paper No 13/2013, Deutsche Bundesbank.

Wooldridge, J. (2006) Introductory Econometrics: A Modern Approach, 3rd Ed. 
Figure 1. Euro Area Financial and Non-Financial Corporate Bond Spreads (Relative to German Bund Rates)

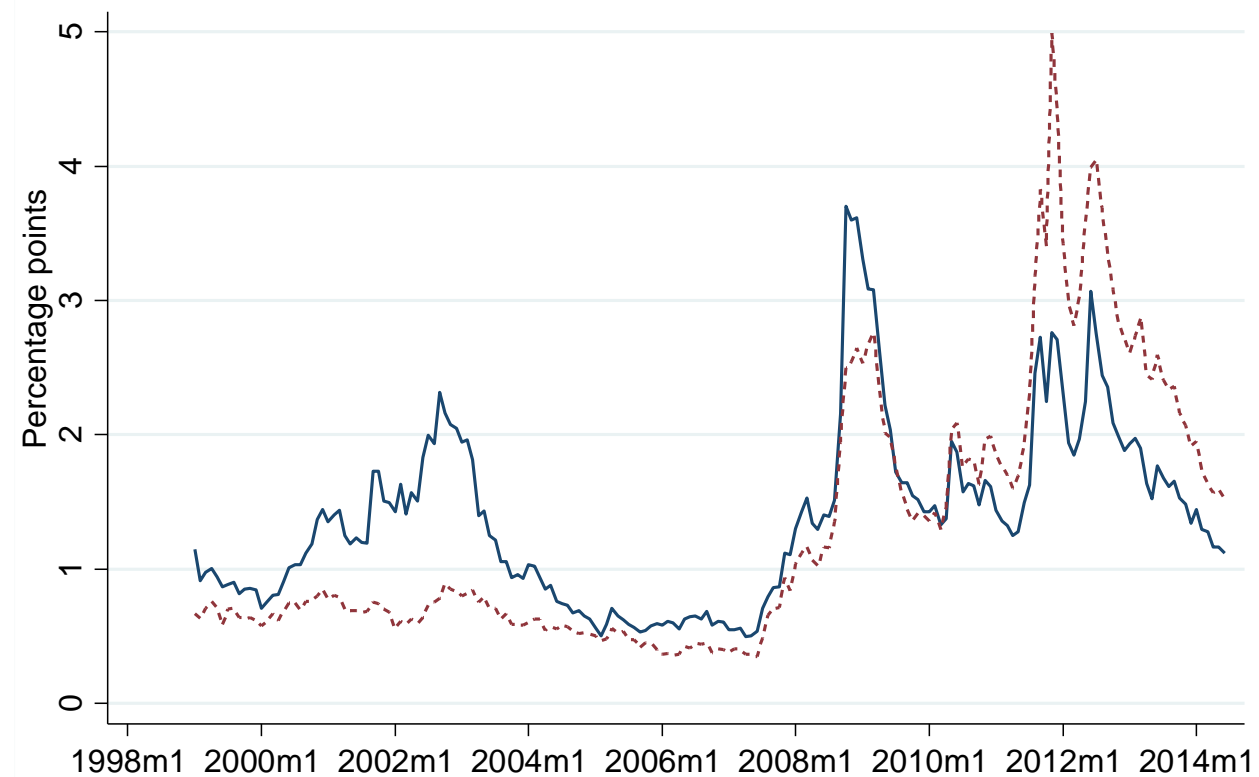

EA Non-financial Spreads (-........ EA Financial Spreads

Notes: The figure reports the average monthly value of the spreads over the German Bund rate for financial and non-financial corporate bonds in the euro area at each point in time.

Figure 2. Corporate Bond Gross Issuance by Country (constant Euro Bn)

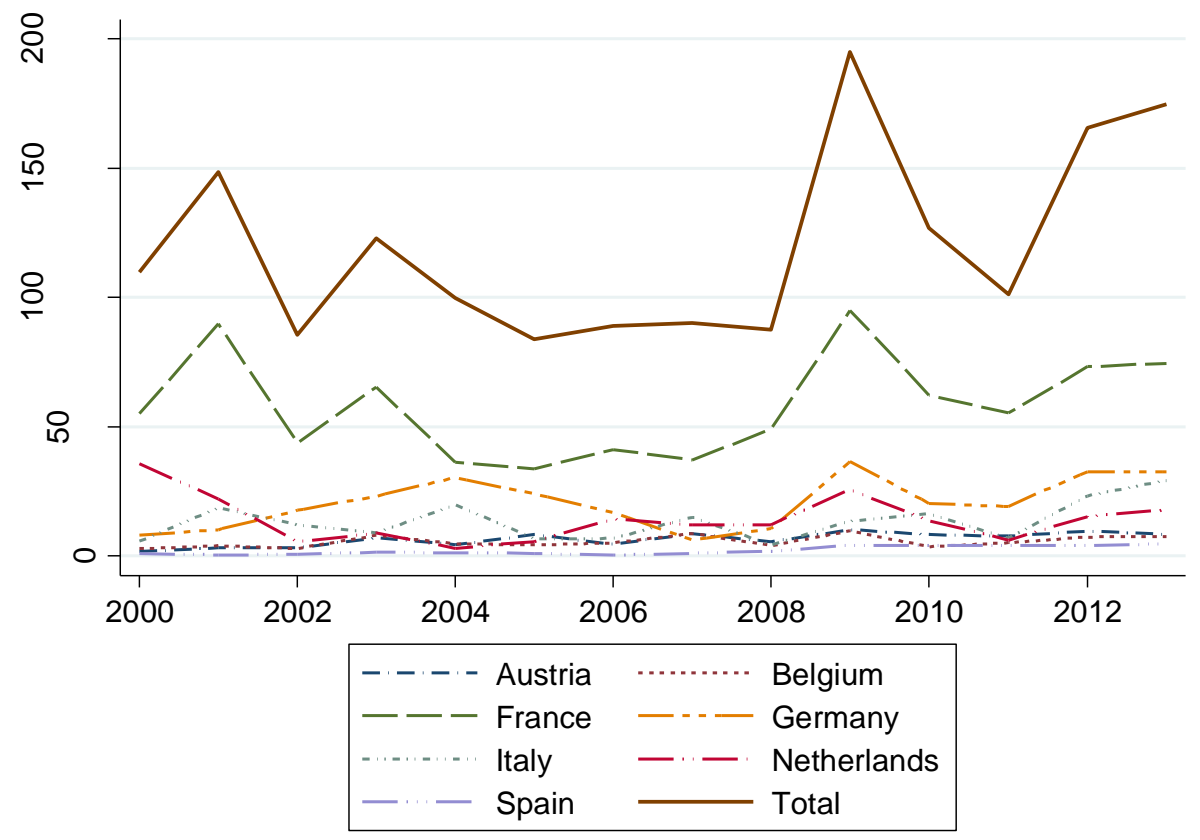

Notes: The figure shows the gross issuance patterns of corporate bonds by country since 2000 . The values are adjusted to real terms using the relevant country GDP deflator $(2010=100)$. 
Figure 3a. Non-Financial Corporations Debt Securities, Volumes Outstanding (constant Euro bn) in Dec. 1998, Dec. 2007 and Dec. 2013

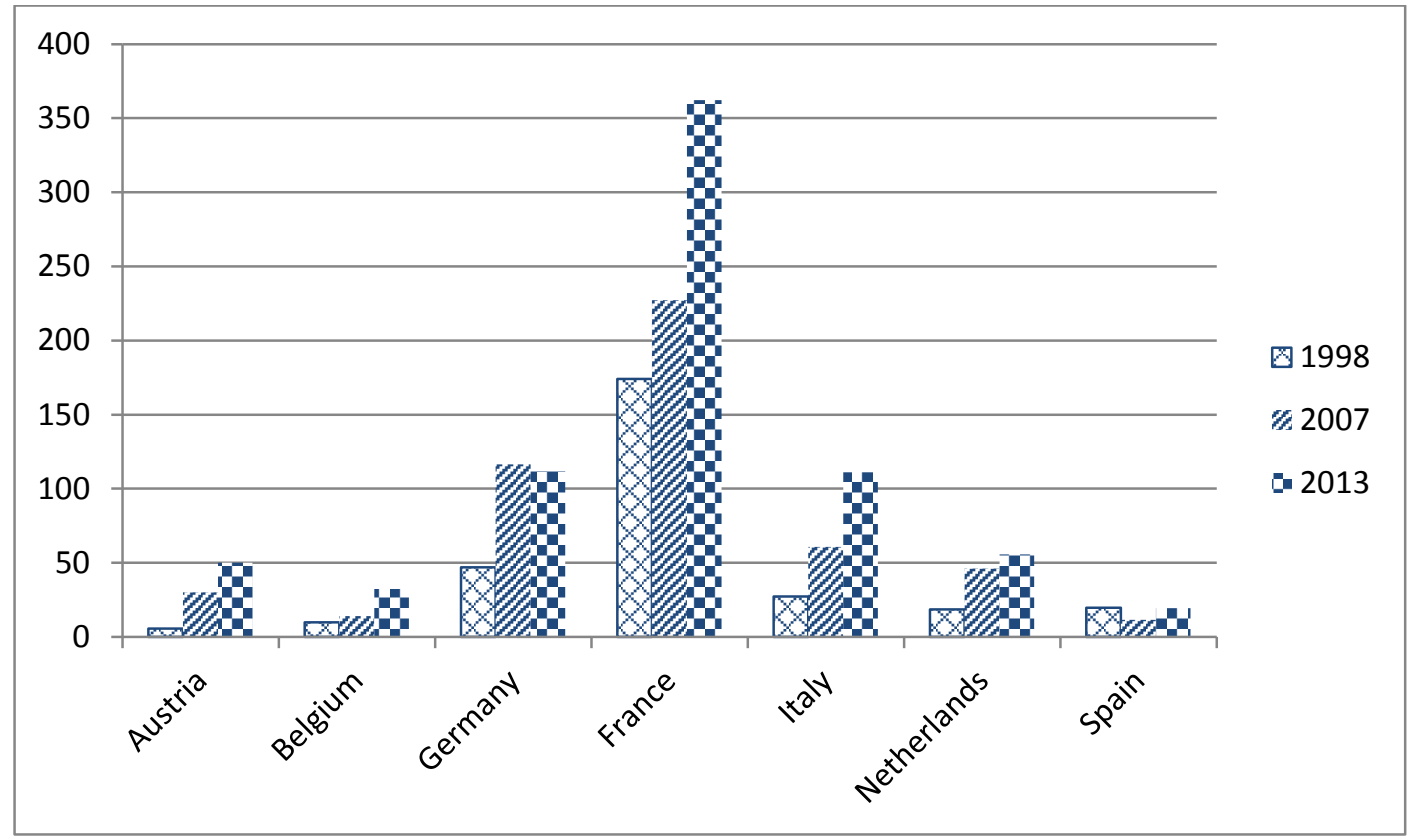

Notes: The figure shows the volume of non-financial corporations debt securities by country at the end of 1998, 2007 and 2013. The values are adjusted to real terms using the relevant country GDP deflator $(2010=100)$.

Figure 3b. Non-Financial Corporations Debt Securities, Volumes Outstanding as a Percentage of GDP, as of Dec. 1998, Dec. 2007 and Dec. 2013

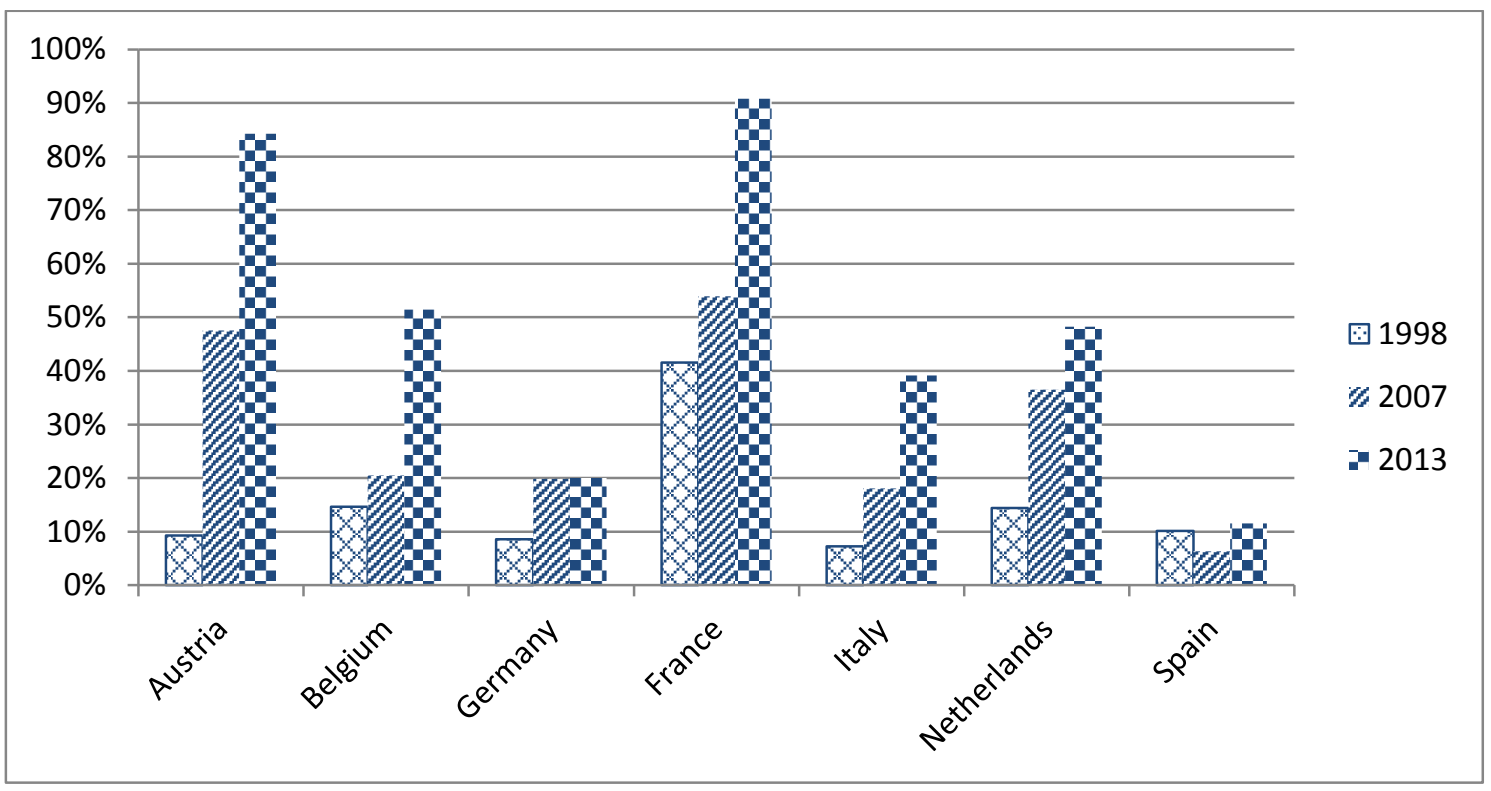

Notes: The figure shows the volume of non-financial corporations debt securities by country at the end of 1998,2007 and 2013 relative to GDP. 
Figure 4. The Bond Spread by Country

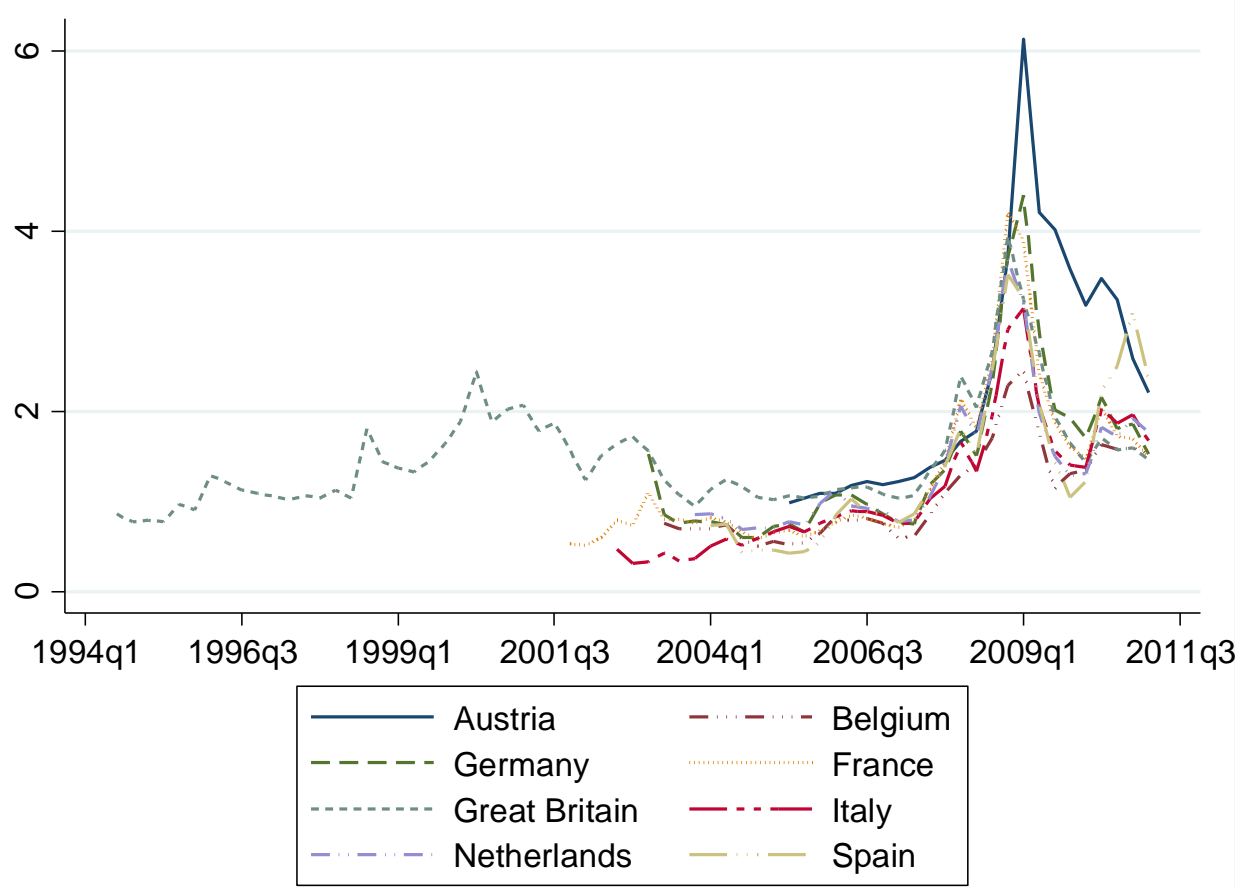

Notes: The figure shows the bond spread over the theoretical risk free rate by country.

Figure 5. The Moody's KMV Expected Default Frequency (EDF) by Country

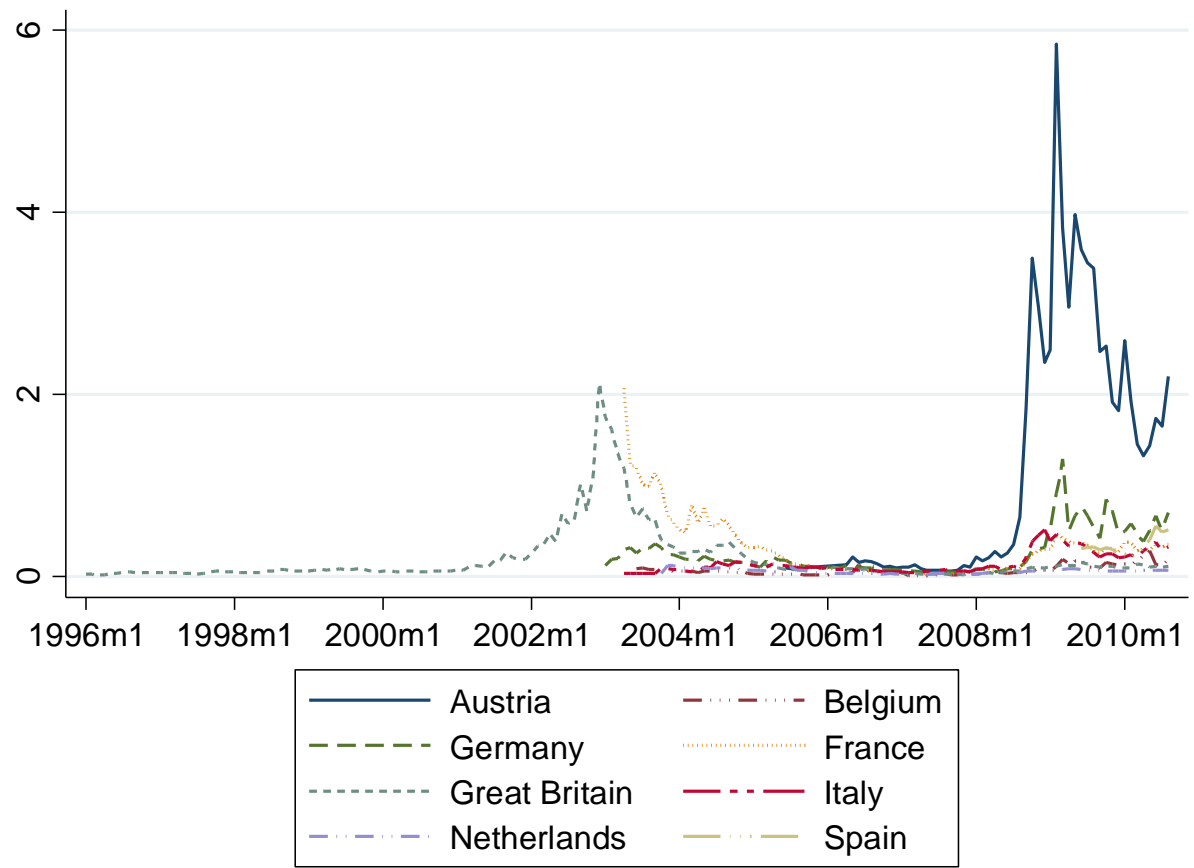

Notes: The figure shows the Moody's KMV expected default frequency by country. 
Figure 6. The First Principal Component and the Bond Spread

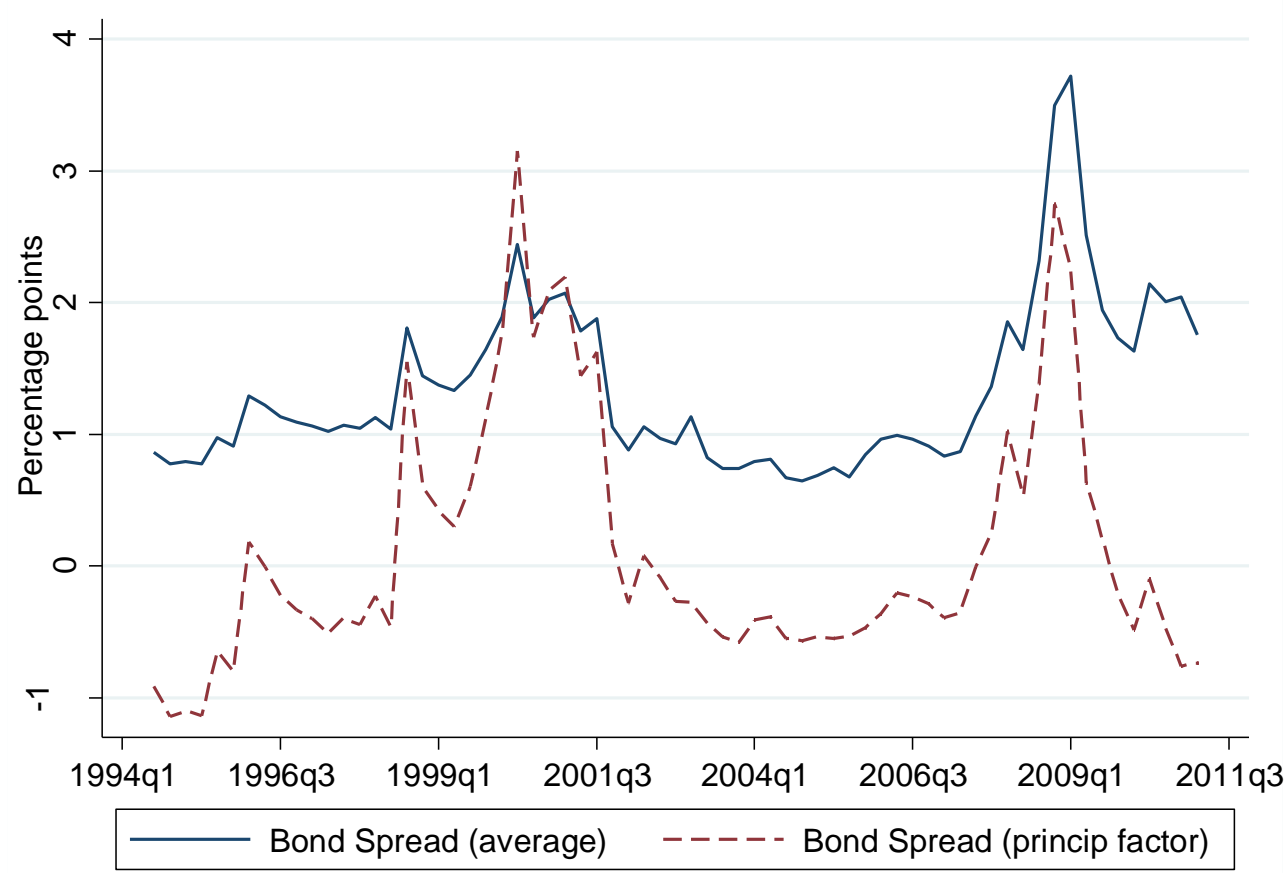

Notes: The figure shows the bond spread over the theoretical risk free rate averaged across all countries in our sample versus the principal component extracted from the bond spread.

Figure 7. The Actual and Predicted Spreads

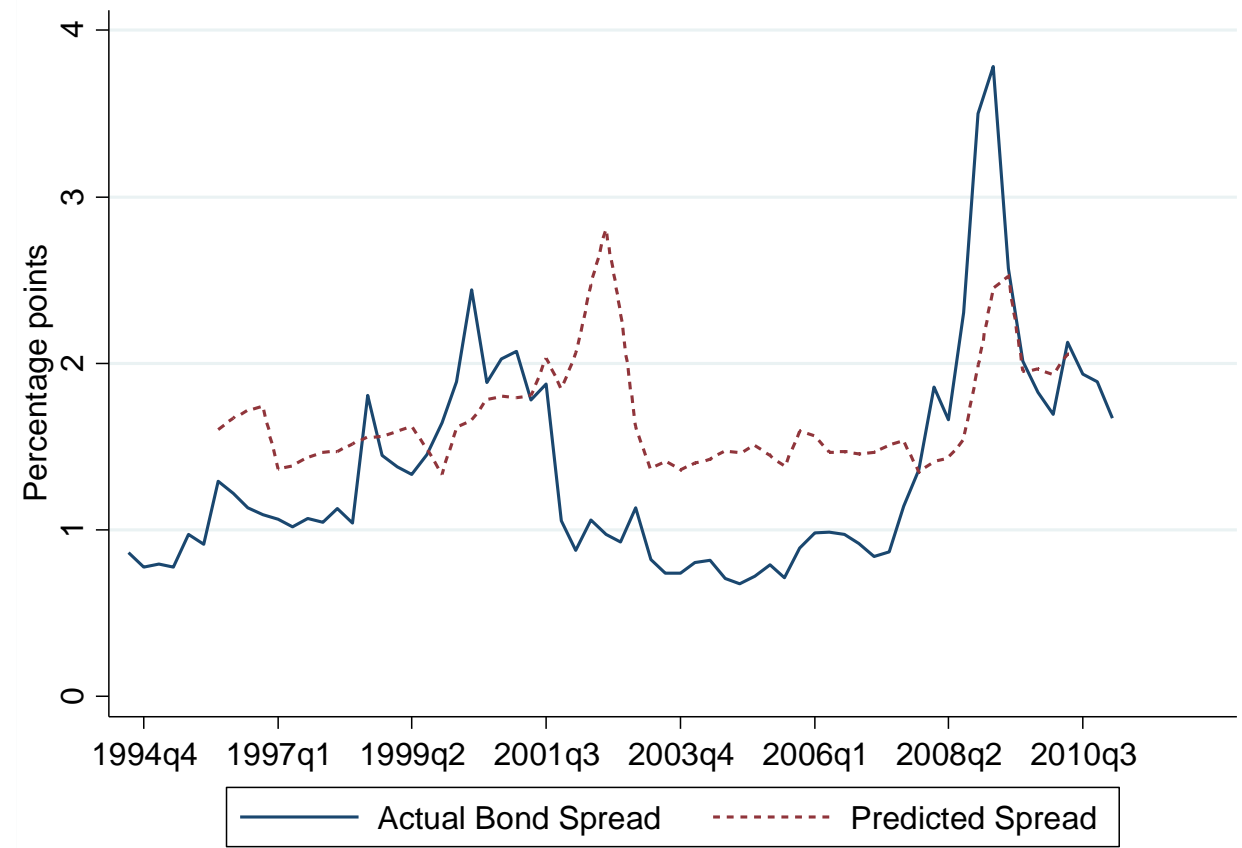

Notes: The figure shows the average bond spread and the predicted part of the average bond spread obtained using the level and squared value of the expected default frequency measure and bond characteristics (equation 4b). 
Figure 8. The Excess Bond Premium (EBP)

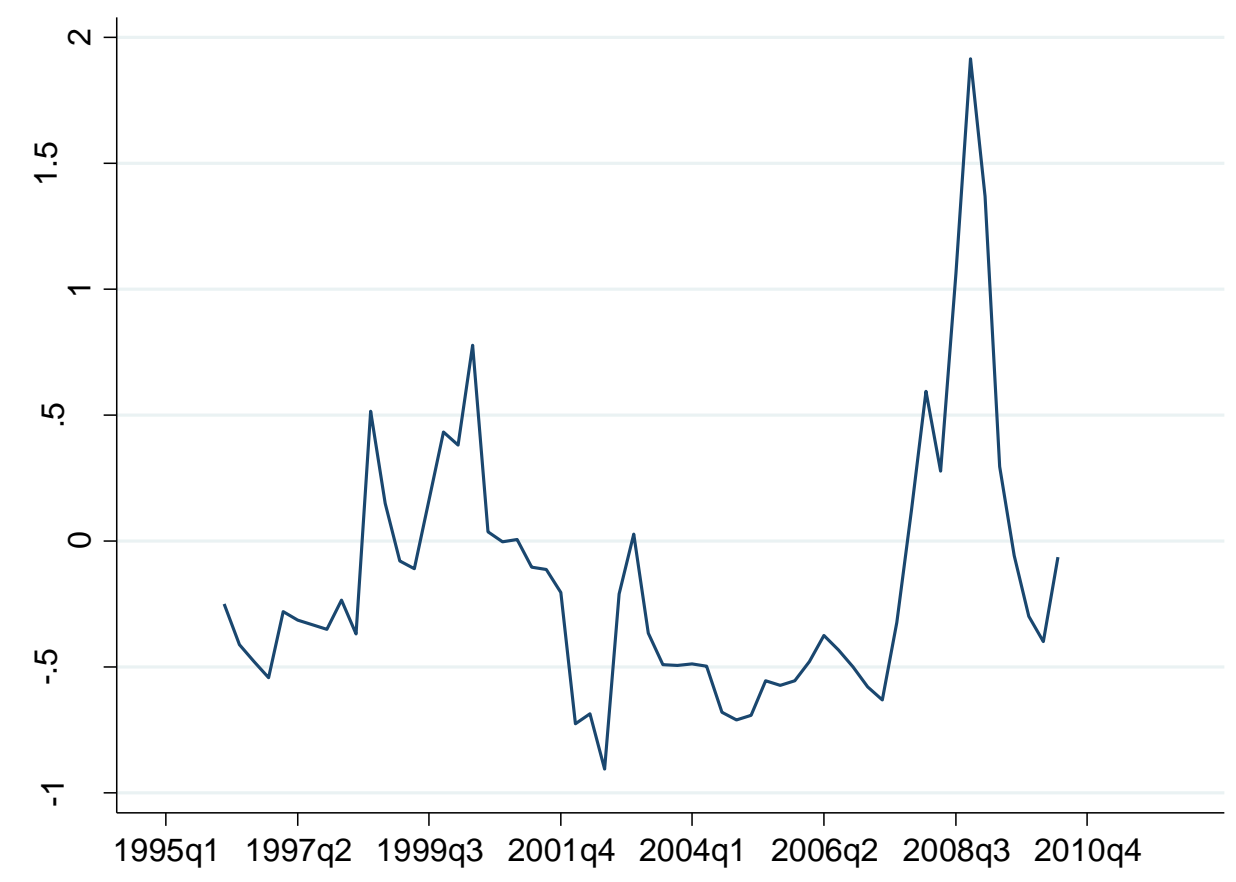

Notes: The figure shows the residual from equation (4b) which measures the excess bond premium.

Figure 9. The ECB BLS Credit Tightness Indicator and the EBP (Next Three Months)

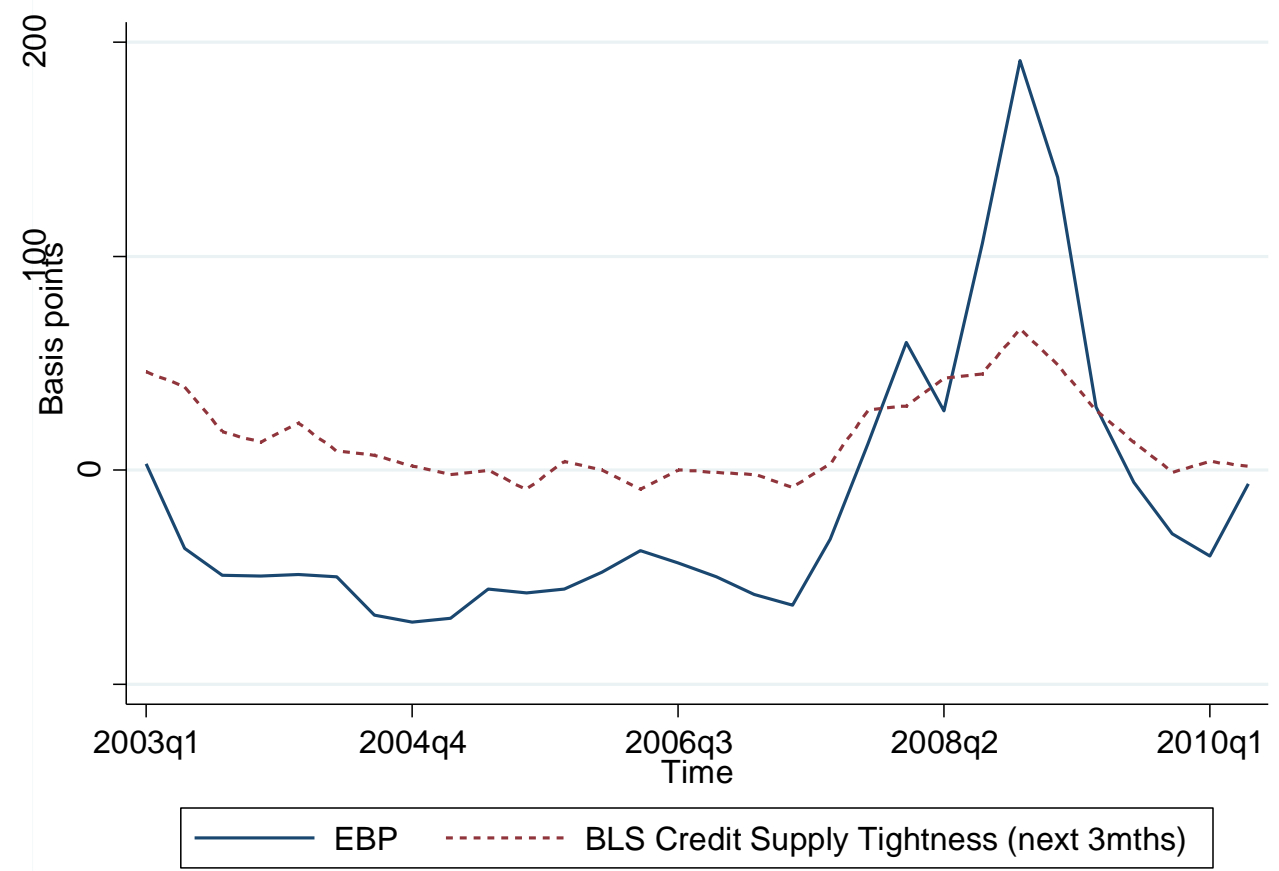


Notes: The figure shows the excess bond premium versus the Bank Lending Survey credit supply tightness measure obtained from the European Central Bank. The tightness refers to the conditions survey respondents expect to prevail over the next three months.

Table 1a. Descriptive Statistics for the Whole Sample

\begin{tabular}{lrrrrr}
\hline \hline Variable (bond level) & Obs. & Mean & Std. Dev. & Min & Max \\
\hline No. of bonds/firm & 19574 & 4.91 & 3.26 & 1 & 13 \\
Nominal yield (\%) & 19574 & 4.87 & 1.73 & 0.3 & 29.85 \\
Risk-free rate (\%) & 19574 & 3.16 & 1.17 & 0.41 & 8.44 \\
Bond spread (\%) & 19554 & 1.71 & 1.53 & 0.015 & 27.95 \\
Bloomberg Z-spread (\%) & 13958 & 1.42 & 1.44 & 0.0001 & 23.38 \\
Coupon (\%) & 19574 & 5.36 & 1.19 & 0.5 & 8.875 \\
Duration (yrs.) & 18988 & 7.06 & 3.39 & 0.79 & 16.79 \\
Term to maturity (yrs.) & 19574 & 9.66 & 6.68 & 1.04 & 31.98 \\
Age (yrs.) & 19439 & 2.94 & 2.61 & 0 & 16.78 \\
Maturity at issue (yrs.) & 19574 & 12.58 & 7.35 & 3 & 40.03 \\
Amount outstanding (€mil.) & 19574 & 614 & 405 & 7.73 & 3,270 \\
Amount issued (€mil.) & 19574 & 643 & 425 & 10 & 3,500 \\
S\&P rating & 17311 & - & - & $\mathrm{B}-$ & $\mathrm{AA}$ \\
\hline Variable (country level) & & & & & \\
\hline Bond Spread (\%) & 872 & 1.4 & 0.85 & 0.32 & 6.13 \\
Country CLI & 872 & 100.39 & 3.22 & 85.6 & 105.8 \\
Term spread & 872 & 1.509 & 1.18 & -2.182 & 3.368 \\
Real interest rate & 872 & 1.265 & 1.561 & -0.851 & 6.302 \\
\hline
\end{tabular}


Table 1b. Descriptive Statistics

\begin{tabular}{|c|c|c|c|c|c|c|c|c|c|c|c|c|c|c|}
\hline Country & Statistics & $\begin{array}{r}\text { No. of } \\
\text { bonds/firm }\end{array}$ & $\begin{array}{l}\text { Nominal } \\
\text { yield (\%) }\end{array}$ & $\begin{array}{r}\text { Risk- } \\
\text { free } \\
\text { rate } \\
(\%)\end{array}$ & $\begin{array}{r}\text { Bond } \\
\text { spread } \\
(\%)\end{array}$ & $\begin{array}{r}\text { Bloomberg } \\
\text { Z-spread (\%) }\end{array}$ & $\begin{array}{r}\text { Coupon } \\
(\%)\end{array}$ & $\begin{array}{r}\text { Duration } \\
\text { (yrs.) }\end{array}$ & $\begin{array}{r}\text { Term to } \\
\text { Maturity } \\
\text { (yrs.) }\end{array}$ & $\begin{array}{r}\text { Age } \\
\text { (yrs.) }\end{array}$ & $\begin{array}{r}\text { Maturity } \\
\text { at issue } \\
\text { (yrs.) }\end{array}$ & $\begin{array}{r}\text { Amt } \\
\text { outstanding } \\
(E m i l .)\end{array}$ & $\begin{array}{r}\text { Amt } \\
\text { issued } \\
\text { (€mil.) }\end{array}$ & EDF \\
\hline \multirow[t]{5}{*}{ AT } & $N$ & 674 & 674 & 674 & 674 & 606 & 674 & 391 & 674 & 669 & 674 & 674 & 674 & 199 \\
\hline & Mean & 2.040 & 0.052 & 2.4 & 2.802 & 2.454 & 5.159 & 4.180 & 4.836 & 1.631 & 6.455 & 184 & 187 & 1.420 \\
\hline & SD & 1.079 & 0.019 & 1.043 & 2.127 & 2.176 & 1.044 & 1.484 & 1.809 & 1.302 & 1.588 & 192 & 190 & 1.713 \\
\hline & Min & 1 & 0.023 & 0.509 & 0.862 & 0.533 & 3.875 & 0.996 & 1.052 & 0 & 4.003 & 10 & 10 & 0.049 \\
\hline & Max & 4 & 0.126 & 4.561 & 10.725 & 10.101 & 8.750 & 8.330 & 9.989 & 5.619 & 10.008 & 1,000 & 1,000 & 7.516 \\
\hline \multirow[t]{5}{*}{$\mathrm{BE}$} & $N$ & 527 & 527 & 527 & 527 & 408 & 527 & 504 & 527 & 519 & 527 & 527 & 527 & 295 \\
\hline & Mean & 2.435 & 0.040 & 2.7 & 1.338 & 1.005 & 4.850 & 5.570 & 6.677 & 2.309 & 8.950 & 444 & 444 & 0.094 \\
\hline & SD & 0.744 & 0.009 & 0.991 & 0.685 & 0.657 & 0.615 & 2.215 & 3.003 & 2.031 & 3.503 & 251 & 251 & 0.130 \\
\hline & Min & 1 & 0.019 & 0.630 & 0.336 & 0.165 & 3.875 & 1.660 & 1.712 & 0 & 4.003 & 25 & 25 & 0.010 \\
\hline & Max & 3 & 0.067 & 4.639 & 3.767 & 3.295 & 6.750 & 11.263 & 15.003 & 7.932 & 15.011 & 950 & 950 & 1.390 \\
\hline \multirow[t]{5}{*}{$\mathrm{DE}$} & $N$ & 1909 & 1909 & 1909 & 1909 & 1260 & 1909 & 1838 & 1909 & 1893 & 1909 & 1909 & 1909 & 600 \\
\hline & Mean & 2.395 & 0.044 & 2.7 & 1.748 & 1.482 & 5.007 & 5.650 & 7.035 & 2.223 & 9.239 & 703 & 720 & 0.390 \\
\hline & SD & 1.179 & 0.018 & 1.065 & 1.693 & 1.916 & 1.065 & 2.860 & 5.134 & 1.884 & 5.602 & 324 & 316 & 0.914 \\
\hline & Min & 1 & 0.015 & 0.567 & 0.332 & 0.019 & 2.250 & 1.073 & 1.326 & 0 & 3.003 & 10 & 10 & 0.010 \\
\hline & Max & 4 & 0.257 & 4.909 & 23.793 & 23.380 & 8.000 & 15.992 & 30.060 & 8.296 & 30.022 & 2,000 & 2,000 & 7.958 \\
\hline \multirow[t]{5}{*}{ FR } & $N$ & 7627 & 7627 & 7627 & 7609 & 5930 & 7627 & 7428 & 7627 & 7560 & 7627 & 7627 & 7627 & 3932 \\
\hline & Mean & 6.544 & 0.046 & 2.9 & 1.717 & 1.305 & 5.127 & 6.248 & 7.904 & 2.489 & 10.370 & 766 & 814 & 0.244 \\
\hline & SD & 3.495 & 0.019 & 1.031 & 1.810 & 1.441 & 1.073 & 2.804 & 4.989 & 2.030 & 5.329 & 469 & 506 & 0.619 \\
\hline & Min & 1 & 0.003 & 0.415 & 0.015 & 0.000 & 0.500 & 0.809 & 1.063 & 0 & 3.003 & 8 & 15 & 0.010 \\
\hline & Max & 13 & 0.298 & 5.330 & 27.947 & 15.803 & 8.625 & 16.792 & 30.014 & 9.647 & 30.022 & 3,270 & 3,500 & 12.394 \\
\hline
\end{tabular}


Table 1b. Descriptive Statistics (Cont.)

\begin{tabular}{|c|c|c|c|c|c|c|c|c|c|c|c|c|c|c|}
\hline Country & Statistics & $\begin{array}{r}\text { No. of } \\
\text { bonds/firm }\end{array}$ & $\begin{array}{l}\text { Nominal } \\
\text { yield (\%) }\end{array}$ & $\begin{array}{r}\text { Risk- } \\
\text { free } \\
\text { rate } \\
(\%) \\
\end{array}$ & $\begin{array}{r}\text { Bond } \\
\text { spread } \\
(\%)\end{array}$ & $\begin{array}{r}\text { Bloomberg } \\
\text { Z-spread (\%) }\end{array}$ & $\begin{array}{r}\text { Coupon } \\
(\%)\end{array}$ & $\begin{array}{r}\text { Duration } \\
\text { (yrs.) }\end{array}$ & $\begin{array}{r}\text { Term to } \\
\text { Maturity } \\
\text { (yrs.) }\end{array}$ & $\begin{array}{r}\text { Age } \\
\text { (yrs.) }\end{array}$ & $\begin{array}{r}\text { Maturity } \\
\text { at issue } \\
\text { (yrs.) }\end{array}$ & $\begin{array}{r}\text { Amt } \\
\text { outstanding } \\
(€ \text { mil.) }\end{array}$ & $\begin{array}{r}\text { Amt } \\
\text { issued } \\
(€ m i l .)\end{array}$ & EDF \\
\hline \multirow[t]{5}{*}{ GB } & $N$ & 4661 & 4661 & 4661 & 4661 & 3036 & 4661 & 4661 & 4661 & 4636 & 4661 & 4661 & 4661 & 1716 \\
\hline & Mean & 3.355 & 0.058 & 4.2 & 1.664 & 1.564 & 6.352 & 9.860 & 15.817 & 4.428 & 20.233 & 360 & 385 & 0.188 \\
\hline & SD & 1.857 & 0.013 & 1.004 & 1.129 & 1.279 & 1.215 & 3.641 & 7.889 & 3.570 & 7.989 & 176 & 166 & 0.862 \\
\hline & Min & 1 & 0.017 & 0.718 & 0.512 & 0.148 & 4.625 & 1.042 & 1.186 & 0 & 5.003 & 23 & 23 & 0.010 \\
\hline & Max & 7 & 0.152 & 8.439 & 12.529 & 11.980 & 8.875 & 16.654 & 31.981 & 16.781 & 40.027 & 1,030 & 1,030 & 17.915 \\
\hline \multirow[t]{5}{*}{ IT } & $\mathrm{N}$ & 1918 & 1918 & 1918 & 1916 & 943 & 1918 & 1917 & 1918 & 1914 & 1918 & 1918 & 1918 & 813 \\
\hline & Mean & 5.407 & 0.045 & 3.1 & 1.441 & 1.385 & 5.017 & 6.769 & 8.924 & 2.969 & 11.887 & 750 & 753 & 0.197 \\
\hline & SD & 3.144 & 0.013 & 0.995 & 1.084 & 1.035 & 0.763 & 2.777 & 5.026 & 2.219 & 5.328 & 396 & 394 & 0.355 \\
\hline & Min & 1 & 0.017 & 0.518 & 0.092 & 0.170 & 2.731 & 1.041 & 1.093 & 0 & 4.008 & 40 & 40 & 0.010 \\
\hline & Max & 9 & 0.140 & 4.855 & 11.566 & 7.490 & 8.250 & 13.307 & 24.271 & 8.915 & 29.022 & 2,000 & 2,000 & 3.309 \\
\hline \multirow[t]{5}{*}{ NL } & $N$ & 1872 & 1872 & 1872 & 1872 & 1659 & 1872 & 1870 & 1872 & 1864 & 1872 & 1872 & 1872 & 630 \\
\hline & Mean & 5.842 & 0.046 & 2.9 & 1.683 & 1.286 & 4.898 & 6.167 & 7.678 & 2.344 & 10.011 & 623 & 646 & 0.061 \\
\hline & SD & 3.285 & 0.014 & 0.983 & 1.064 & 1.048 & 0.884 & 2.358 & 3.815 & 1.775 & 3.801 & 258 & 274 & 0.031 \\
\hline & Min & 1 & 0.017 & 0.507 & 0.301 & 0.002 & 3.250 & 0.992 & 1.036 & 0 & 4.003 & 30 & 30 & 0.010 \\
\hline & Max & 11 & 0.150 & 4.857 & 12.172 & 11.449 & 7.500 & 13.471 & 20.022 & 8.066 & 20.014 & 1,400 & 1,400 & 0.271 \\
\hline \multirow[t]{5}{*}{ SP } & $\mathrm{N}$ & 386 & 386 & 386 & 386 & 116 & 386 & 386 & 386 & 384 & 386 & 386 & 386 & 30 \\
\hline & Mean & 5.078 & 0.047 & 2.8 & 1.860 & 1.436 & 4.659 & 6.356 & 8.864 & 3.159 & 12.006 & 512 & 512 & 0.342 \\
\hline & SD & 1.687 & 0.014 & 1.069 & 1.068 & 1.000 & 0.622 & 3.179 & 7.098 & 2.307 & 6.546 & 259 & 259 & 0.103 \\
\hline & Min & 2 & 0.019 & 0.522 & 0.412 & 0.221 & 3.250 & 0.790 & 1.101 & 0 & 3.003 & 125 & 125 & 0.208 \\
\hline & Max & 6 & 0.087 & 4.753 & 4.867 & 3.992 & 5.990 & 13.600 & 29.890 & 7.882 & 30.019 & 1,000 & 1,000 & 0.562 \\
\hline
\end{tabular}

Notes: Sample period July 1994 - May 2011; No. of bonds = 500; No. of firms = 190; No. of months = 203; No. of industry sectors = 45; No. of bonds/months for Austria (AT) (33/69), Belgium (BE) (24/96), France (FR) (207/116), Germany (DE) (61/101), Great Britain (GB) (74/203), Italy (IT) (46/107), Netherlands (NL) (45/92), and Spain (SP) (10/88). Euroarea countries included from October 2001. There are 2 observations with a bond spread of less than 5 bps and 67 observations ( 12 bonds) that have a term to maturity higher than 30 years. The bond spreads for these observations is however within the range of the full bonds sample and have therefore been included. 
Table 2: Four Real Activity Measures and Bond Spreads

\begin{tabular}{|c|c|c|c|c|}
\hline \multicolumn{5}{|c|}{ Forecast Horizon: Either $\mathbf{1 2}$ months or $\mathbf{4}$ quarters } \\
\hline \multicolumn{5}{|c|}{ Estimator: Dynamic FE } \\
\hline Financial Indicator & $\begin{array}{l}\text { RGDP } \\
(1)\end{array}$ & $\begin{array}{c}\text { EMP } \\
(2) \\
\end{array}$ & $\begin{array}{l}\text { INV } \\
(3)\end{array}$ & $\begin{array}{l}\text { IP } \\
\text { (4) }\end{array}$ \\
\hline Bond Spread & $\begin{array}{c}-1.292^{* * *} \\
(0.377)\end{array}$ & $\begin{array}{c}-0.494^{* * *} \\
(0.132)\end{array}$ & $\begin{array}{c}-3.288^{* * *} \\
(0.911)\end{array}$ & $\begin{array}{c}-3.648 * * * \\
(1.107)\end{array}$ \\
\hline Real Interest Rate & $\begin{array}{l}-0.167 \\
(0.276)\end{array}$ & $\begin{array}{l}-0.187 \\
(0.123)\end{array}$ & $\begin{array}{l}-0.639 \\
(0.710)\end{array}$ & $\begin{array}{l}-1.068 \\
(0.706)\end{array}$ \\
\hline Term Spread & $\begin{array}{l}-0.066 \\
(0.376)\end{array}$ & $\begin{array}{l}-0.103 \\
(0.122)\end{array}$ & $\begin{array}{c}0.179 \\
(0.931)\end{array}$ & $\begin{array}{c}0.37 \\
(0.985)\end{array}$ \\
\hline Country CLI & $\begin{array}{c}0.545^{* * *} \\
(0.165)\end{array}$ & $\begin{array}{c}0.236 * * * \\
(0.043)\end{array}$ & $\begin{array}{c}1.373^{* * *} \\
(0.246)\end{array}$ & $\begin{array}{c}1.969 * * * \\
(0.401)\end{array}$ \\
\hline Within R-sq & 0.423 & 0.535 & 0.483 & 0.798 \\
\hline \multicolumn{5}{|c|}{ Forecast Horizon: Either $\mathbf{1 2}$ months or $\mathbf{4}$ quarters } \\
\hline \multicolumn{5}{|c|}{ Estimator: MGE } \\
\hline Financial Indicator & $\begin{array}{c}\text { RGDP } \\
(5)\end{array}$ & $\begin{array}{c}\text { EMP } \\
(6)\end{array}$ & $\begin{array}{l}\text { INV } \\
(7)\end{array}$ & $\begin{array}{l}\text { IP } \\
\text { (8) }\end{array}$ \\
\hline Bond Spread & $\begin{array}{c}-1.345^{* * *} \\
(0.399)\end{array}$ & $\begin{array}{l}-0.378^{*} \\
(0.195)\end{array}$ & $\begin{array}{c}-3.473 * * \\
(1.616)\end{array}$ & $\begin{array}{c}-3.899 * * * \\
(0.693)\end{array}$ \\
\hline Real Interest Rate & $\begin{array}{c}-1.678 * * * \\
(0.420)\end{array}$ & $\begin{array}{c}-0.638^{* * *} \\
(0.228)\end{array}$ & $\begin{array}{c}-4.528 * * * \\
(1.140)\end{array}$ & $\begin{array}{c}-5.578 * * * \\
(1.269)\end{array}$ \\
\hline Term Spread & $\begin{array}{c}-1.732^{* * *} \\
(0.534)\end{array}$ & $\begin{array}{c}-0.663^{* * *} \\
(0.150)\end{array}$ & $\begin{array}{c}-4.430 * * * \\
(1.485)\end{array}$ & $\begin{array}{c}-3.792 * * * \\
(1.250)\end{array}$ \\
\hline Country CLI & $\begin{array}{c}0.741^{* * *} \\
(0.165)\end{array}$ & $\begin{array}{c}0.438 * * \\
(0.216)\end{array}$ & $\begin{array}{c}1.555^{* * *} \\
(0.428)\end{array}$ & $\begin{array}{c}2.583^{* * *} \\
(0.376)\end{array}$ \\
\hline RMSE & 1.190 & 0.438 & 2.872 & 4.383 \\
\hline Observations & 287 & 287 & 287 & 872 \\
\hline Number of countries & 8 & 8 & 8 & 8 \\
\hline Hausman stat. $\left(\chi_{1}^{2}\right)$ & 0.165 & 0.653 & 0.019 & 0.085 \\
\hline
\end{tabular}

Notes. The dependent variable in each column is annualised quarterly Real GDP growth (RGDP), Employment growth (EMP), Fixed Capital Investment growth (INV) and monthly growth in Industrial Production (IP). The top panel reports dynamic fixed effects estimates and the bottom panel reports mean-group estimates of the same equation (2) using monetary policy indicators (Real Interest Rate and Term Spread), the Country Composite Leading Indicator (Country CLI) and the bond spread measure (Bond Spread). Sample period: July 1994 - May 2011. Euroarea countries are included from October 2001. All models include 5 lags of the first-difference growth of the dependent variable. Standard errors are reported in parentheses. ${ }^{* * *} p<0.01,{ }^{* *} p<0.05,{ }^{*} p<0.1$. The Hausman statistic tests for evidence of bias in the dynamic fixed effects estimate of the coefficient for the bond spread with a null of no difference between the estimated coefficients in the top and bottom panels, and therefore no bias. The critical values are $6.635(p<0.01), 3.841(p<0.05)$ and $2.706(p<0.1)$. 
Table 3. Real GDP Growth and Bond Spreads

\begin{tabular}{|c|c|c|c|}
\hline \multicolumn{4}{|c|}{ Real GDP Growth } \\
\hline \multicolumn{4}{|c|}{ Estimator: Dynamic FE } \\
\hline Financial Indicator & $\begin{array}{c}1 \text { quarter } \\
\text { (1) }\end{array}$ & $\begin{array}{c}4 \text { quarters } \\
\text { (2) }\end{array}$ & $\begin{array}{c}8 \text { quarters } \\
\text { (3) }\end{array}$ \\
\hline Bond Spread & $\begin{array}{c}-1.309 * * * \\
(0.218)\end{array}$ & $\begin{array}{c}-1.292^{* * *} \\
(0.377)\end{array}$ & $\begin{array}{c}-1.124^{* * *} \\
(0.373)\end{array}$ \\
\hline Real Interest Rate & $\begin{array}{l}0.0571 \\
(0.217)\end{array}$ & $\begin{array}{l}-0.167 \\
(0.276)\end{array}$ & $\begin{array}{r}-0.0152 \\
(0.277)\end{array}$ \\
\hline Term Spread & $\begin{array}{l}-0.137 \\
(0.253)\end{array}$ & $\begin{array}{l}-0.066 \\
(0.376)\end{array}$ & $\begin{array}{c}0.29 \\
(0.401)\end{array}$ \\
\hline Country CLI & $\begin{array}{c}1.057^{* * *} \\
(0.204)\end{array}$ & $\begin{array}{c}0.545^{* * *} \\
(0.165)\end{array}$ & $\begin{array}{l}-0.001 \\
(0.111)\end{array}$ \\
\hline Within R-sq & 0.696 & 0.423 & 0.201 \\
\hline \multicolumn{4}{|c|}{ Estimator: MGE } \\
\hline Financial Indicator & $\begin{array}{c}1 \text { quarter } \\
\text { (4) }\end{array}$ & $\begin{array}{c}4 \text { quarters } \\
\text { (5) }\end{array}$ & $\begin{array}{c}8 \text { quarters } \\
\text { (6) }\end{array}$ \\
\hline Bond Spread & $\begin{array}{c}-1.464 * * * \\
(0.407)\end{array}$ & $\begin{array}{c}-1.345^{* * *} \\
(0.399)\end{array}$ & $\begin{array}{c}-1.446 * * * \\
(0.228)\end{array}$ \\
\hline Real Interest Rate & $\begin{array}{l}-0.397 \\
(0.265)\end{array}$ & $\begin{array}{c}-1.678^{* * *} \\
(0.420)\end{array}$ & $\begin{array}{c}-1.448^{* * *} \\
(0.311)\end{array}$ \\
\hline Term Spread & $\begin{array}{c}-0.813^{* *} \\
(0.355)\end{array}$ & $\begin{array}{c}-1.732 * * * \\
(0.534)\end{array}$ & $\begin{array}{c}-0.918^{* * *} \\
(0.283)\end{array}$ \\
\hline Country CLI & $\begin{array}{c}1.426 * * * \\
(0.201)\end{array}$ & $\begin{array}{c}0.741^{* * *} \\
(0.165) \\
\end{array}$ & $\begin{array}{c}-0.175^{* *} \\
(0.081)\end{array}$ \\
\hline RMSE & 1.054 & 1.190 & 1.052 \\
\hline Observations & 287 & 287 & 287 \\
\hline Number of countries & 8 & 8 & 8 \\
\hline Hausman stat. $\left(\chi^{2}{ }_{1}\right)$ & 0.203 & 0.165 & 1.190 \\
\hline
\end{tabular}

Notes: The dependent variable in each column is annualised quarterly Real GDP growth (RGDP). See notes to Table 2. 
Table 4. Results Using the First Principal Component of Bond Spreads

\begin{tabular}{|c|c|c|c|}
\hline \multicolumn{4}{|c|}{ Real GDP Growth } \\
\hline \multicolumn{4}{|c|}{ Estimator: Dynamic FE } \\
\hline Financial Indicator & $\begin{array}{c}1 \text { quarter } \\
\text { (1) }\end{array}$ & $\begin{array}{c}4 \text { quarters } \\
\text { (2) }\end{array}$ & $\begin{array}{c}8 \text { quarters } \\
\text { (3) }\end{array}$ \\
\hline Bond Spread PC & $\begin{array}{c}-0.809 * * * \\
(0.160)\end{array}$ & $\begin{array}{c}-0.564 * * \\
(0.223)\end{array}$ & $\begin{array}{c}-0.383^{*} \\
(0.207)\end{array}$ \\
\hline Real Interest Rate & $\begin{array}{c}0.134 \\
(0.249)\end{array}$ & $\begin{array}{l}-0.167 \\
(0.327)\end{array}$ & $\begin{array}{c}-0.05 \\
(0.333)\end{array}$ \\
\hline Term Spread & $\begin{array}{c}-0.442 \\
(0.287)\end{array}$ & $\begin{array}{c}-0.39 \\
(0.451)\end{array}$ & $\begin{array}{c}-0.00191 \\
(0.501)\end{array}$ \\
\hline Country CLI & $\begin{array}{c}1.046 * * * \\
(0.223) \\
\end{array}$ & $\begin{array}{c}0.597^{* * *} \\
(0.206)\end{array}$ & $\begin{array}{c}0.073 \\
(0.135) \\
\end{array}$ \\
\hline Within R-sq & 0.673 & 0.352 & 0.091 \\
\hline \multicolumn{4}{|c|}{ Estimator: MGE } \\
\hline Financial Indicator & $\begin{array}{c}1 \text { quarter } \\
\text { (4) }\end{array}$ & $\begin{array}{c}4 \text { quarters } \\
\text { (5) }\end{array}$ & $\begin{array}{c}8 \text { quarters } \\
\text { (6) }\end{array}$ \\
\hline Bond Spread PC & $\begin{array}{c}-0.970 * * * \\
(0.183)\end{array}$ & $\begin{array}{l}-0.828^{*} \\
(0.437)\end{array}$ & $\begin{array}{l}-0.748^{*} \\
(0.401)\end{array}$ \\
\hline Real Interest Rate & $\begin{array}{l}-0.331 \\
(0.318)\end{array}$ & $\begin{array}{c}-1.719 * * * \\
(0.409)\end{array}$ & $\begin{array}{c}-1.628 * * * \\
(0.313)\end{array}$ \\
\hline Term Spread & $\begin{array}{c}-1.132 * * * \\
(0.313)\end{array}$ & $\begin{array}{c}-1.952 * * * \\
(0.461)\end{array}$ & $\begin{array}{c}-1.364 * * * \\
(0.326)\end{array}$ \\
\hline Country CLI & $\begin{array}{c}1.246 * * * \\
(0.178) \\
\end{array}$ & $\begin{array}{c}0.802 * * * \\
(0.251) \\
\end{array}$ & $\begin{array}{c}-0.00556 \\
(0.154) \\
\end{array}$ \\
\hline RMSE & 1.138 & 1.279 & 1.159 \\
\hline Observations & 287 & 287 & 287 \\
\hline Number of countries & 8 & 8 & 8 \\
\hline Hausman stat. $\left(\chi^{2}{ }_{1}\right)$ & 3.286 & 0.493 & 1.129 \\
\hline
\end{tabular}

Notes: The dependent variable in each column is annualised Real GDP growth (RGDP). See notes to Table 2. 
Table 5. Additional Variables to Explain Real GDP Growth

\begin{tabular}{|c|c|c|c|}
\hline \multicolumn{4}{|c|}{ Real GDP Growth } \\
\hline \multicolumn{4}{|c|}{ Estimator: Dynamic FE } \\
\hline Financial Indicator & $\begin{array}{l}1 \text { quarter } \\
\text { (1) }\end{array}$ & $\begin{array}{c}4 \text { quarters } \\
\text { (2) }\end{array}$ & $\begin{array}{c}8 \text { quarters } \\
\text { (3) }\end{array}$ \\
\hline Bond Spread & $\begin{array}{c}-0.744 * * * \\
(0.241)\end{array}$ & $\begin{array}{l}-0.923^{*} \\
(0.500)\end{array}$ & $\begin{array}{l}-0.92{ }^{*} \\
(0.494)\end{array}$ \\
\hline Real Interest Rate & $\begin{array}{r}-0.0339 \\
(0.229)\end{array}$ & $\begin{array}{l}-0.237 \\
(0.296)\end{array}$ & $\begin{array}{c}-0.0244 \\
(0.286)\end{array}$ \\
\hline Term Spread & $\begin{array}{l}-0.304 \\
(0.265)\end{array}$ & $\begin{array}{l}-0.175 \\
(0.480)\end{array}$ & $\begin{array}{c}0.26 \\
(0.466)\end{array}$ \\
\hline Country CLI & $\begin{array}{c}0.762 * * * \\
(0.160)\end{array}$ & $\begin{array}{c}0.510 * * \\
(0.218)\end{array}$ & $\begin{array}{l}0.0716 \\
(0.117)\end{array}$ \\
\hline US CLI & $\begin{array}{r}-0.0503 \\
(0.165)\end{array}$ & $\begin{array}{l}-0.451 * \\
(0.252)\end{array}$ & $\begin{array}{c}-0.437^{* *} \\
(0.216)\end{array}$ \\
\hline US IP Growth & $\begin{array}{c}0.189 * * * \\
(0.060)\end{array}$ & $\begin{array}{c}0.190 * * * \\
(0.071)\end{array}$ & $\begin{array}{c}0.121 * * \\
(0.056)\end{array}$ \\
\hline Within R-sq & 0.742 & 0.471 & 0.215 \\
\hline & Estimator: $\mathrm{N}$ & & \\
\hline Financial Indicator & $\begin{array}{c}1 \text { quarter } \\
\text { (4) }\end{array}$ & $\begin{array}{c}4 \text { quarters } \\
\text { (5) }\end{array}$ & $\begin{array}{c}8 \text { quarters } \\
\text { (6) }\end{array}$ \\
\hline Bond Spread & $\begin{array}{c}-1.387^{* * *} \\
(0.378)\end{array}$ & $\begin{array}{c}-1.561^{* * *} \\
(0.392)\end{array}$ & $\begin{array}{c}-1.688^{* * *} \\
(0.240)\end{array}$ \\
\hline Real Interest Rate & $\begin{array}{l}-0.359 \\
(0.290)\end{array}$ & $\begin{array}{c}-1.271^{* * *} \\
(0.430)\end{array}$ & $\begin{array}{c}-1.056^{* * *} \\
(0.303)\end{array}$ \\
\hline Term Spread & $\begin{array}{l}-0.649 * \\
(0.383)\end{array}$ & $\begin{array}{c}-1.310^{* *} \\
(0.556)\end{array}$ & $\begin{array}{c}-0.603 * \\
(0.355)\end{array}$ \\
\hline Country CLI & $\begin{array}{c}1.019 * * * \\
(0.361)\end{array}$ & $\begin{array}{c}1.470 * * * \\
(0.368)\end{array}$ & $\begin{array}{c}0.762 * * * \\
(0.282)\end{array}$ \\
\hline US CLI & $\begin{array}{c}0.391 \\
(0.378)\end{array}$ & $\begin{array}{c}-0.579 * * * \\
(0.213)\end{array}$ & $\begin{array}{c}-0.859 * * * \\
(0.285)\end{array}$ \\
\hline US IP Growth & $\begin{array}{l}0.0271 \\
(0.030) \\
\end{array}$ & $\begin{array}{r}-0.0425 \\
(0.035) \\
\end{array}$ & $\begin{array}{c}-0.0520 * * \\
(0.024)\end{array}$ \\
\hline RMSE & 0.9250 & 1.1247 & 0.9580 \\
\hline Observations & 255 & 255 & 255 \\
\hline Number of countries & 8 & 8 & 8 \\
\hline
\end{tabular}

Notes: The dependent variable in each column is annualised Real GDP growth (RGDP). The top panel provides estimates from dynamic fixed effects estimates of equation (2) using monetary policy indicators (Real Interest Rate and Term Spread), the composite leading indicators for the European country (Country CLI) and US (US CLI), the US Industrial Production firstdifference growth rate (US IP Growth), and the bond spread (Bond Spread). The lower panel provides mean group estimates of the same model. Sample period: July 1994 - May 2011. Euroarea countries included from October 2001. All models include 5 lags of the first-difference growth of the dependent variable. Standard errors are reported in parentheses. $* * *$ $\mathrm{p}<0.01, * * \mathrm{p}<0.05, * \mathrm{p}<0.1$. 
Table 6. Real GDP Growth and Country-Specific Responses to Bond Spreads

\begin{tabular}{|c|c|c|c|}
\hline \multicolumn{4}{|c|}{ Real GDP Growth } \\
\hline \multicolumn{4}{|c|}{ Estimator: Dynamic FE } \\
\hline Financial Indicator & $\begin{array}{c}1 \text { quarter } \\
\text { (1) }\end{array}$ & $\begin{array}{l}4 \text { quarters } \\
\text { (2) }\end{array}$ & $\begin{array}{c}8 \text { quarters } \\
\text { (3) }\end{array}$ \\
\hline Term Spread & $\begin{array}{l}-0.297 \\
(0.273)\end{array}$ & $\begin{array}{l}-0.206 \\
(0.357)\end{array}$ & $\begin{array}{c}0.228 \\
(0.384)\end{array}$ \\
\hline Real Interest Rate & $\begin{array}{l}0.0108 \\
(0.219)\end{array}$ & $\begin{array}{l}-0.198 \\
(0.282)\end{array}$ & $\begin{array}{l}-0.0159 \\
(0.251)\end{array}$ \\
\hline Bond Spread AT & $\begin{array}{c}-0.788 * * * \\
(0.255)\end{array}$ & $\begin{array}{c}-0.608 * * \\
(0.293)\end{array}$ & $\begin{array}{l}-0.314 \\
(0.368)\end{array}$ \\
\hline Bond Spread BE & $\begin{array}{c}-1.865 * * * \\
(0.533)\end{array}$ & $\begin{array}{c}-1.789 * * \\
(0.686)\end{array}$ & $\begin{array}{c}-1.564^{* * *} \\
(0.473)\end{array}$ \\
\hline Bond Spread FR & $\begin{array}{c}-0.970 * * * \\
(0.199)\end{array}$ & $\begin{array}{c}-0.973 * * * \\
(0.337)\end{array}$ & $\begin{array}{c}-0.889 * * * \\
(0.320)\end{array}$ \\
\hline Bond Spread DE & $\begin{array}{c}-1.013^{* *} \\
(0.494)\end{array}$ & $\begin{array}{l}-0.547 \\
(0.446)\end{array}$ & $\begin{array}{l}-0.444 \\
(0.402)\end{array}$ \\
\hline Bond Spread GB & $\begin{array}{c}-2.675^{* * *} \\
(0.538)\end{array}$ & $\begin{array}{c}-2.587 * * * \\
(0.675)\end{array}$ & $\begin{array}{c}-1.988 * * * \\
(0.584)\end{array}$ \\
\hline Bond Spread IT & $\begin{array}{c}-1.570^{* * *} \\
(0.565)\end{array}$ & $\begin{array}{c}-1.542^{* * *} \\
(0.566)\end{array}$ & $\begin{array}{c}-1.478^{* * *} \\
(0.444)\end{array}$ \\
\hline Bond Spread NL & $\begin{array}{c}-1.330 * * * \\
(0.358)\end{array}$ & $\begin{array}{c}-1.690 * * \\
(0.680)\end{array}$ & $\begin{array}{c}-1.819 * * * \\
(0.581)\end{array}$ \\
\hline Bond Spread SP & $\begin{array}{c}-1.499 * * * \\
(0.494)\end{array}$ & $\begin{array}{c}-2.171 * * * \\
(0.409)\end{array}$ & $\begin{array}{c}-2.278 * * * \\
(0.587)\end{array}$ \\
\hline Country CLI & $\begin{array}{c}1.040 * * * \\
(0.205)\end{array}$ & $\begin{array}{c}0.507^{* * *} \\
(0.170)\end{array}$ & $\begin{array}{l}-0.0574 \\
(0.110)\end{array}$ \\
\hline R-sq & 0.7202 & 0.4853 & 0.3131 \\
\hline Observations & 287 & 287 & 287 \\
\hline Number of countries & 8 & 8 & 8 \\
\hline F-test $p$-value (ALL) & $0.000 * * *$ & $0.000 * * *$ & $0.000 * * *$ \\
\hline F-test $p$-value (ex GB) & $0.001 * * *$ & $0.000 * * *$ & $0.000 * * *$ \\
\hline F-test $p$-value (FR, DE, NL) & 0.701 & 0.148 & $0.021 * *$ \\
\hline
\end{tabular}

Notes: The dependent variable in each column is annualised Real GDP growth (RGDP). See notes to Table 2. Ftests at the foot of the table test for equality of coefficients for all countries, all countries excluding Great Britain, and just for France, Germany and the Netherlands respectively. ${ }^{* * *} p<0.01,{ }^{* *} p<0.05,{ }^{*} p<0.1$. 
Table 7. Prediction of Bond Spreads

\begin{tabular}{ccc}
\hline \hline Variable & $\mathbf{( 1 )}$ & $\mathbf{( 2 )}$ \\
\hline \hline $\operatorname{Ln}(1+E D F)$ & $0.856^{* * *}$ & $1.342^{* * *}$ \\
& $(0.326)$ & $(0.368)$ \\
{$[\operatorname{Ln}(1+E D F)]^{2}$} & - & $-5.897^{* * *}$ \\
& & $(2.164)$ \\
$\operatorname{Ln}(1+C P N)$ & $0.132^{* * *}$ & $0.123^{* * *}$ \\
& $(0.031)$ & $(0.031)$ \\
{$[\operatorname{Ln}(1+D U R)] / 100$} & $-0.288^{*}$ & -0.243 \\
& $(0.168)$ & $(0.156)$ \\
{$[\operatorname{Ln}(A O S)] / 100$} & -0.0579 & -0.0715 \\
& $(0.086)$ & $(0.084)$ \\
{$[\operatorname{Ln}(1+A G E)] / 100$} & $0.202^{* * *}$ & $0.197^{* * *}$ \\
& $(0.043)$ & $(0.044)$ \\
\hline Observations & 7,640 & 7,640 \\
R-squared & 0.468 & 0.480 \\
Industry Effects & 0.000 & 0.000 \\
Bond Rating Effects & 0.000 & 0.000 \\
\hline
\end{tabular}

Notes: The dependent variable in each column is $\ln (1+$ bond spread). Estimates of equations $(4 a-4 b)$ using bond characteristics and expected default frequency to decompose the bond spread measure. The fitted value from this equation provides the predicted spread measure used in Table 8 and 9, and the residuals are the Excess Bond Premium also used in Table 8. Sample period: January 1996 - August 2010. Euroarea countries included from February 2003. Standard errors (in parentheses) clustered at country and time dimensions. They include country dummies which are not reported. *** $p<0.01, * * p<0.05,{ }^{*} p<0.1$ 
Table 8. Real GDP Growth and the Excess Bond Premium

\begin{tabular}{|c|c|c|c|}
\hline \multicolumn{4}{|c|}{ Real GDP Growth } \\
\hline \multicolumn{4}{|c|}{ Estimator: Dynamic FE } \\
\hline Financial Indicator & $\begin{array}{c}1 \text { quarter } \\
\text { (1) }\end{array}$ & $\begin{array}{l}4 \text { quarters } \\
\text { (2) }\end{array}$ & $\begin{array}{c}8 \text { quarters } \\
\text { (3) }\end{array}$ \\
\hline Term Spread & $\begin{array}{c}-1.063^{* * *} \\
(0.373)\end{array}$ & $\begin{array}{l}-0.605 \\
(0.530)\end{array}$ & $\begin{array}{l}0.0991 \\
(0.449)\end{array}$ \\
\hline Real Interest Rate & $\begin{array}{l}0.0753 \\
(0.237)\end{array}$ & $\begin{array}{l}-0.102 \\
(0.362)\end{array}$ & $\begin{array}{l}0.0954 \\
(0.302)\end{array}$ \\
\hline Predicted Spread (lag) & $\begin{array}{c}0.458 \\
(0.342)\end{array}$ & $\begin{array}{c}0.24 \\
(0.389)\end{array}$ & $\begin{array}{l}-0.148 \\
(0.362)\end{array}$ \\
\hline EBP AT & $\begin{array}{l}-0.352 \\
(0.811)\end{array}$ & $\begin{array}{l}-1.003 \\
(0.768)\end{array}$ & $\begin{array}{c}-1.202 * \\
(0.641)\end{array}$ \\
\hline EBP BE & $\begin{array}{c}-3.282 * * * \\
(1.092)\end{array}$ & $\begin{array}{c}-2.730 * * * \\
(0.957)\end{array}$ & $\begin{array}{c}-1.757^{* * *} \\
(0.547)\end{array}$ \\
\hline EBP FR & $\begin{array}{c}-1.829 * * * \\
(0.233)\end{array}$ & $\begin{array}{c}-1.739 * * * \\
(0.617)\end{array}$ & $\begin{array}{c}-1.496 * * * \\
(0.521)\end{array}$ \\
\hline EBP DE & $\begin{array}{c}-2.193 * * * \\
(0.424)\end{array}$ & $\begin{array}{c}-1.238 * * \\
(0.477)\end{array}$ & $\begin{array}{c}-0.625^{* *} \\
(0.304)\end{array}$ \\
\hline EBP GB & $\begin{array}{c}-3.246 * * * \\
(0.398)\end{array}$ & $\begin{array}{c}-2.798 * * * \\
(0.682)\end{array}$ & $\begin{array}{c}-2.152^{* * *} \\
(0.404)\end{array}$ \\
\hline EBP IT & $\begin{array}{c}-2.949 * * * \\
(0.457)\end{array}$ & $\begin{array}{c}-2.334^{* * *} \\
(0.705)\end{array}$ & $\begin{array}{c}-1.472 * * * \\
(0.500)\end{array}$ \\
\hline EBP NL & $\begin{array}{c}-1.241 * * * \\
(0.357)\end{array}$ & $\begin{array}{c}-1.495^{* * *} \\
(0.479)\end{array}$ & $\begin{array}{c}-1.577^{* * *} \\
(0.386)\end{array}$ \\
\hline Country CLI & $\begin{array}{c}0.750 * * * \\
(0.162) \\
\end{array}$ & $\begin{array}{c}0.338^{* *} \\
(0.159) \\
\end{array}$ & $\begin{array}{l}-0.116 \\
(0.119) \\
\end{array}$ \\
\hline R-sq & 0.787 & 0.537 & 0.311 \\
\hline Observations & 206 & 206 & 206 \\
\hline Number of countries & 7 & 7 & 7 \\
\hline F-test $p$-value (ALL) & $0.000 * * *$ & $0.025^{* *}$ & $0.000 * * *$ \\
\hline F-test $p$-value (ex GB) & $0.004^{* * *}$ & $0.015^{* *}$ & $0.000 * * *$ \\
\hline F-test $p$-value (FR, DE, NL) & $0.042 * *$ & 0.469 & $0.000 * * *$ \\
\hline
\end{tabular}

Notes: The dependent variable in each column is annualised Real GDP growth (RGDP). The results are reported for dynamic fixed-effects estimates of equation (7) including 5 lags of the first-difference growth of the dependent variable, monetary policy indicators (Real Interest Rate and Term Spread), the country composite leading indicator (Country CLI), the predicted Spread from Table 7 and the Excess Bond Premium (EBP) interacted with respective country dummies. Sample period: January 1996 - August 2010. Euroarea countries are included from February 2003. Spain drops out due to a limited sample of bond issuing firms. Standard errors are reported in parentheses. ${ }^{* * *} \mathrm{p}<0.01,{ }^{* *} \mathrm{p}<0.05,{ }^{*} \mathrm{p}<0.1$. F-tests at the foot of the table test for equality of coefficients for all countries, all countries excluding Great Britain, and just for France, Germany and the Netherlands respectively. 
Table 9. Credit Supply Tightness, Credit Demand and Real GDP Growth

\begin{tabular}{|c|c|c|c|}
\hline \multicolumn{4}{|c|}{ Real GDP Growth } \\
\hline \multicolumn{4}{|c|}{ Estimator: Dynamic FE } \\
\hline Financial Indicator & $\begin{array}{c}1 \text { quarter } \\
\text { (1) }\end{array}$ & $\begin{array}{c}4 \text { quarters } \\
\text { (2) }\end{array}$ & $\begin{array}{c}8 \text { quarters } \\
\text { (3) }\end{array}$ \\
\hline Predicted Spread (lag) & $\begin{array}{c}0.608^{* * *} \\
(0.214)\end{array}$ & $\begin{array}{c}0.371 \\
(0.246)\end{array}$ & $\begin{array}{c}0.13 \\
(0.127)\end{array}$ \\
\hline BLS Credit Supply & $\begin{array}{c}-0.0530 * * \\
(0.024)\end{array}$ & $\begin{array}{c}-0.0763^{* * *} \\
(0.024)\end{array}$ & $\begin{array}{c}-0.0261^{*} \\
(0.013)\end{array}$ \\
\hline Real Interest Rate & $\begin{array}{c}-0.887^{* *} \\
(0.434)\end{array}$ & $\begin{array}{c}-1.607^{* * *} \\
(0.420)\end{array}$ & $\begin{array}{c}-1.842^{* * *} \\
(0.386)\end{array}$ \\
\hline Term Spread & $\begin{array}{c}-1.508 * * \\
(0.588)\end{array}$ & $\begin{array}{c}-1.007 * * \\
(0.444)\end{array}$ & $\begin{array}{c}-0.901 * * * \\
(0.322)\end{array}$ \\
\hline OECD CLI & $\begin{array}{c}0.812^{* * *} \\
(0.186)\end{array}$ & $\begin{array}{c}0.165 \\
(0.148)\end{array}$ & $\begin{array}{c}-0.0676 \\
(0.091)\end{array}$ \\
\hline Within R-sq & 0.734 & 0.733 & 0.554 \\
\hline \multicolumn{4}{|c|}{ Estimator: Dynamic FE } \\
\hline Financial Indicator & $\begin{array}{c}1 \text { quarter } \\
\text { (1) }\end{array}$ & $\begin{array}{c}4 \text { quarters } \\
\text { (2) }\end{array}$ & $\begin{array}{c}8 \text { quarters } \\
\text { (3) }\end{array}$ \\
\hline Predicted Spread (lag) & $\begin{array}{c}0.552 * * \\
(0.211)\end{array}$ & $\begin{array}{c}0.354 \\
(0.232)\end{array}$ & $\begin{array}{c}0.111 \\
(0.122)\end{array}$ \\
\hline BLS Credit Supply & $\begin{array}{c}-0.0593^{*} \\
(0.030)\end{array}$ & $\begin{array}{c}-0.0601 * * * \\
(0.015)\end{array}$ & $\begin{array}{c}-0.0290 * * \\
(0.014)\end{array}$ \\
\hline BLS Credit Demand & $\begin{array}{c}-0.0149 \\
(0.035)\end{array}$ & $\begin{array}{l}0.0411 \\
(0.025)\end{array}$ & $\begin{array}{c}-0.00699 \\
(0.016)\end{array}$ \\
\hline Real Interest Rate & $\begin{array}{c}-0.926^{* *} \\
(0.450)\end{array}$ & $\begin{array}{c}-1.483^{* * *} \\
(0.419)\end{array}$ & $\begin{array}{c}-1.861 * * * \\
(0.382)\end{array}$ \\
\hline Term Spread & $\begin{array}{c}-1.531^{* *} \\
(0.599)\end{array}$ & $\begin{array}{c}-0.868^{*} \\
(0.461)\end{array}$ & $\begin{array}{c}-0.916 * * \\
(0.339)\end{array}$ \\
\hline OECD CLI & $\begin{array}{c}0.852^{* * *} \\
(0.245)\end{array}$ & $\begin{array}{l}0.0537 \\
(0.166) \\
\end{array}$ & $\begin{array}{l}-0.0486 \\
(0.091)\end{array}$ \\
\hline Within R-sq & 0.734 & 0.750 & 0.555 \\
\hline Observations & 186 & 186 & 186 \\
\hline Number of countries & 7 & 7 & 7 \\
\hline
\end{tabular}

Notes: The dependent variable in each column is annualised Real GDP growth (RGDP). Dynamic Fixed-Effects estimates of equation (2) using monetary policy indicators (Real Interest Rate and Term Spread), the country composite leading indicator (Country CLI), the predicted spread component from Table 7 and the two ECB Bank Lending Survey (BLS) 3-month forward looking measures of tightening credit supply and credit demand by enterprises. Sample period: January 1996 - August 2010. Euroarea countries included from February 2003 (BLS is available from January 2003). All models include 5 lags of the firstdifference growth of the dependent variable. Spain drops out due to a limited sample of bond issuing firms. Standard errors are reported in parentheses. ${ }^{* * *} p<0.01,{ }^{* *} p<0.05, * p<0.1$. 